\title{
Crédito para la frontera. Negociación institucional, coerción militar y financiación de la Real Hacienda en el Río de la Plata borbónico (1767-1777)
}

Credit for the Border. Institutional Negotiation, Military Coercion, and Royal Treasury Financing in the Bourbon Rio de la Plata (I767-I777)

DOI: https://10.22380/20274688.660

Recibido: 29 de marzo del 2019

Aprobado: 19 de julio del 2019
MARTÍN LEANDRO EZEQUIEL WASSERMAN*

Instituto de Historia Argentina y Americana

Dr. Emilio Ravignani (Conicet - UBA), Buenos Aires, Argentina martinwasserman@hotmail.com

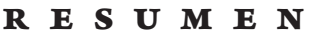

La guerra de los Siete Años (1754-1763) demostró a la Corona española la urgencia de fortalecer la defensa en territorios estratégicos. La tensión entre España y Portugal condujo al gobierno borbónico a robustecer los recursos para la defensa de sus dominios en el Río de la Plata y a implementar reconfiguraciones institucionales concordantes. En ese proceso, una multitud de deudas con actores locales y regionales permitió a la Real Hacienda en Buenos Aires sostener el aparato defensivo.

* Es doctor en Historia de la Facultad de Filosofía y Letras de la Universidad de Buenos Aires (UBA), docente de la cátedra de Historia de América II (Colonial) de la carrera de Historia de la UBA y se desempeña como investigador del Consejo Nacional de Investigaciones Científicas y Técnicas (Conicet), con lugar de trabajo en el Instituto de Historia Argentina y Americana Dr. Emilio Ravignani (UBA-Conicet). https://orcid.org/0000-000I-94I4-7449. 
Si actores comerciales locales encontraban en dicho financiamiento un campo lucrativo, incrementar recursos fiscales con fines militares era un punto de confluencia entre los objetivos de la Corona, la reconfiguración institucional y los intereses de acreedores locales. Así, la mediación de actores locales en el funcionamiento del erario pervivía durante el proceso de centralización institucional borbónica.

Palabras clave: crédito, fiscalidad, sistema defensivo, Real Hacienda, Virreinato del Río de la Plata

\section{$\begin{array}{lllllllll}\mathbf{A} & \mathbf{B} & \mathbf{S} & \mathbf{T} & \mathbf{R} & \mathbf{A} & \mathbf{C} & \mathbf{T}\end{array}$}

The Seven Years' War (1754-1763) demonstrated to the Spanish Crown the urgency to strengthen defense in strategic territories. The tension between Spain and Portugal led the Bourbon government to strengthen resources for the defense of its domains in the Rio de la Plata and to implement concordant institutional reconfigurations. In this process, a multitude of debts with local and regional actors allowed the Royal Treasury in Buenos
Aires to maintain the defensive apparatus. If local commercial actors found in such financing a lucrative field, increasing fiscal resources for military purposes was a point of confluence between the objectives of the Crown, the institutional reconfiguration and the interests of local creditors. Thus, the mediation of local actors in the operation of the royal treasury would survive during the process of Bourbon institutional centralization.

Keywords: credit, fiscal order, defensive system, Royal Treasury, Viceroyalty of the Río de la Plata

\section{Reformar la Hacienda para defender al imperio}

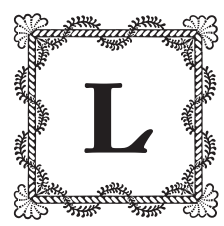

os imperios de la Modernidad participaban de una interrelación estructural entre la necesidad de movilizar recursos para afrontar la conflictividad bélica y las demandas fiscales para subvenir esa movilización; ello hizo de la guerra y el erario dos aristas explicativas de sus dinámicas institucionales (Sánchez, Introducción 8$)^{1}$. En función de ello, la dinastía borbónica en el trono español procuró zas y guerra (Brewer; O’Brien 420,425), y el caso español ha sido sugerido como uno fiscal-militar 
agudizar el control que la Corona ejercía sobre las finanzas imperiales en términos fiscales-militares ${ }^{2}$.

La Real Hacienda, institución elemental para la obtención de aquellos recursos, constituyó por lo tanto el objeto de profundas reformas. El erario regio, que extendía su presencia a los territorios del dominio imperial como hispanus fiscus (Clavero; Sánchez, "El orden”), constituía la materialización institucional y financiera de la monarquía hispánica y, por lo tanto, experimentaría alteraciones también en aquellas latitudes que por fronterizas se revelaban centrales. Reformar la Real Hacienda resultó así un imperativo, con miras a agilizar la consecución de recursos fiscales para el real erario y garantizar su distribución con arreglo al financiamiento de la defensa imperial3.

Si ese proceso de reformulaciones implicó una tendencia a la centralización institucional de la Hacienda y hacia un gobierno más ejecutivo de esta (Dubet; Pinto), la gestión de recursos fiscales no anuló sin embargo la mediación de actores vinculados a la dinámica financiera y comercial de las economías locales sobre las que el hispanus fiscus se desplegaba. Así, la eficacia militar de la Corona estaba condicionada por la capacidad financiera de esos acreedores y proveedores, lo que les confería poder de negociación. No obstante, estos también encontraban en el crédito a la defensa un campo de lucrativos negocios, lo cual hacía del incremento de recursos fiscales con fines militares un punto de confluencia entre los objetivos militares de la Corona y los intereses lucrativos de estos actores (Wasserman, "Real situado").

La guerra de los Siete Años (I754-I763) representó una inflexión, demostró a la Corona española la urgencia de fortalecer la defensa de sus territorios estratégicos (Biangardi). En ese contexto, la tensión entre España y Portugal hizo del Río de la Plata uno de los escenarios de aquella conflictividad imperial, lo cual condujo al gobierno borbónico a robustecer los recursos para la defensa de sus dominios rioplatenses, así como a generar las reconfiguraciones institucionales

subdesarrollado (González; Torres, Elprecio), postulándoselo aun como la verdadera referencia de análisis (Pincus y Robinson).

2 La agudización del control sobre la gestión fiscal no revirtió su relativa ineficacia para afrontar el desafío de hacer la guerra. Esta limitación pudo deberse, al menos en parte, a la dependencia que España tenía respecto de los ingresos americanos (Cuenca-Esteban 247-248).

3 Las reformulaciones borbónicas que avanzaban desde principios del siglo XVIII ya tendían a agilizar la supervisión sobre la gestión de recursos fiscales para efectivizar la autoridad respecto de los gastos militares (Torres, "El gasto"). 
necesarias para que ello fuese posible4. Este propósito colocaba en el centro de la articulación política al real situado, mecanismo mediante el cual tesorerías de distritos con sólidas bases fiscales subsidiaban a tesorerías ubicadas en puntos estratégicos para la defensa del imperio, allí cuando sus recursos impositivos locales resultaran insuficientes para afrontar los gastos defensivos, tal como sucedía con Buenos Aires (Alves y Sánchez; Marichal y Grafenstein 15)`. De este modo, desde la década de 1760 el incremento de recursos destinados al estuario rioplatense mediante el real situado de Buenos Aires, orientado a financiar la defensa del dominio espańol sobre el territorio rioplatense, estuvo acompañado y legitimado por el reposicionamiento del Río de la Plata en el esquema regional de la Real Hacienda, lo cual confirió a la administración del erario regio en Buenos Aires un rol institucionalmente protagónico.

La creación de la Contaduría Mayor de Buenos Aires en 1767 marca el puntapié de estas reconfiguraciones institucionales de la Hacienda en el Río de la Plata. Una medida que formaba parte de las reformulaciones impulsadas por Ortiz de Landazuri en el monitoreo de la Hacienda indiana (Dubet) ${ }^{6}$, en una coyuntura de progresivo belicismo regional que implicó la creciente gravitación de Buenos Aires como centro receptor y redistribuidor de recursos fiscales,

4 El Tratado de Permuta de 1750 establecía que Portugal entregaría a España la Colonia de Sacramento, bajo condición de la previa evacuación de los siete pueblos de indios administrados en territorio oriental por la Compañía de Jesús y su reubicación en la costa occidental del río Uruguay. La eficaz resistencia que los pueblos guaraníes opusieron entre 1754 y 1756 al desalojo de sus misiones orientales permitió al delegado portugués alegar el incumplimiento de aquellas condiciones, lo que dilató la entrega de Colonia a la jurisdicción española. Llegado en 1756 a Buenos Aires, Cevallos estimó inconveniente entregar a Portugal los territorios de las misiones orientales y se dispuso a conquistar Colonia cuando la coyuntura lo posibilitase, ocasión que tuvo lugar en 1762 (Birolo 59). Un año después, al bando lusitano se sumaba la afrenta británica, asediando sin éxito la Colonia recuperada para España (Marchena 20). Sin embargo, la conquista y defensa española caería en la obsolescencia: Colonia era restituida a Portugal con el Tratado de París (1763), resultado de la guerra de los Siete Años. Así, las definiciones imperiales contradecían los resultados de la correlación de fuerzas locales (Birolo 89): la restitución a Portugal tendría efecto el 27 de diciembre de 1763 y la noticia de la paz llegaba a Cevallos mientras este asediaba la región de Río Grande (Marchena 2r).

5 Al igual que en otros distritos fiscales de la Monarquía y en consonancia con la prioridad que todos los gobiernos imperiales daban a la actividad militar durante los siglos XV II y XVIII (Pincus y Robinson; Torres, "El gasto" 27), la Caja porteña también concentraba buena parte de sus desembolsos en erogaciones con fines defensivos.

$6 \quad$ El 12 de noviembre de 1767 Carlos III promulgaba la Instrucción general de la Contaduría de las Indias para el establecimiento del Tribunal de Contaduria Mayor de Cuentas de las Provincias del Rio de la Plata, Paraguay y Tucumán. 
así como un reconocimiento institucional de esa gravitación?. Ello inició un proceso de jerarquización de Buenos Aires dentro del esquema regional de la Real Hacienda, esquema que tendió a una nueva centralización del fisco meridional hispanoamericano con vértice en el estuario rioplatense. La Contaduría Mayor de Cuentas de Buenos Aires, a cargo de revisar las cuentas producidas en Tucumán y Paraguay para su remisión a Lima, detentaba jurisdicción sobre las gobernaciones de Río de la Plata, Paraguay y Tucumán — provincias que dejaban de rendir cuentas directamente a Lima, para pasar a hacerlo a la Contaduría Mayor de Buenos Aires- (Levene 247; Mariluz 133; Rees I08). En I776, en consonancia con la jerarquía que Buenos Aires pasaría a detentar como cabecera del naciente Virreinato del Río de la Plata, la jurisdicción de su contaduría mayor sumaría el control sobre las cuentas de Mendoza y San Juan, sin alcanzar no obstante el monitoreo sobre las cuentas de las provincias norteñas, que por motivos pragmáticos continuaban rindiendo cuentas a Lima (Galarza; véase asimismo Wayar).

El decurso de estas reconfiguraciones en el terreno institucional de la fiscalidad regional tendría largo aliento $^{8}$. En 1780 la Contaduría Mayor de Cuentas habría de transformarse finalmente en Tribunal Mayor de Cuentas (de modo que todo el virreinato pasaría a rendir sus cuentas a esta entidad radicada en Buenos Aires, y ya no a Lima, con lo cual Buenos Aires logró autonomizar

7 Portugal consideraba inaplicable el Tratado de París en la zona meridional brasilera, por lo que en I 767 unos quinientos soldados portugueses atacaron la banda norte de Río Grande y desalojaron de allí a los destacamentos españoles. Vértiz, que reclamaría la devolución, bloqueó Colonia y salió desde Montevideo a Río Grande en 1773 con tropas de Buenos Aires, Santa Fe y Corrientes. Este avance sobre Río Grande generó un débil equilibrio de fuerzas: tras una serie de ofensivas portuguesas en 1775 (en las cuales algunas naves portuguesas ancladas en Colonia atacaron a embarcaciones españolas), Portugal comenzaría a recuperar el territorio riograndense en 1776 (Birolo 175; Marchena 21 y ss.). Ese mismo año de 1767 se ponía en marcha el extrañamiento de la Compañía de Jesús, motivado por la Real Pragmática de ese año; entre tanto, comenzaban las expediciones francoespañolas a Islas Malvinas para disputar el territorio austral a Inglaterra, con bases en Buenos Aires y Montevideo (Wasserman, "Recursos fiscales").

8 Las reconfiguraciones institucionales de la segunda mitad de la década de 1770 no se circunscribían al establecimiento del Virreinato rioplatense: la promulgación del Real Decreto de 1778 para incorporar a Buenos Aires y Montevideo al esquema del comercio libre conllevaba la instauración de la Aduana de Buenos Aires ese mismo año, por cuanto la ampliación del marco monopolista había acelerado el comercio portuario (Gelman y Moraes 54-55), lo que daría lugar a una base imponible en expansión que intentaba ser fiscalizada por la Hacienda. En Montevideo, a su vez, se establecería una Comandancia de Resguardo para controlar el tráfico entre ambas costas fluviales y sus puertos menores (Vaccani). 
su ejercicio fiscal en relación con el Perú y el propio virrey rioplatense, puesto que el Tribunal Mayor de Cuentas respondía directamente a ministerios peninsulares), mientras que en 1782 la Real Ordenanza de Intendentes pasaría a reorganizar las cajas del virreinato en cajas principales ${ }^{9}$ y cajas foráneas ${ }^{10}$. El Tribunal de Cuentas perdería entre tanto su competencia exclusiva con respecto a la constitución de la Junta Superior de Real Hacienda en I782, que pasaba a concentrar la administración de justicia en materia hacendística, la vigilancia de gastos militares y otros atributos (que antes también alcanzaban a la Real Audiencia y a la Junta de Hacienda), lo cual derivó a su vez en conflictos jurisdiccionales, desautorizaciones reales hacia el superintendente y las consecuentes tensiones interinstitucionales en el marco de la administración local de la Real Hacienda (Rees).

Estas reconfiguraciones institucionales que avanzaban desde 1767 no solo expresaban la gravitación creciente de la jurisdicción hacendaria de Buenos Aires, sino que la retroalimentaban con recursos fiscales conducidos por el real situado. Movilizados con motivos defensivos, ponían en marcha mecanismos que incidían sobre la economía local y regional en su conjunto, trascendiendo la dimensión militar que justificaba su envío e involucrando intereses lucrativos del comercio rioplatense.

\section{El real situado de Buenos Aires: conducto de caudales y reformas}

La movilización de caudales implicada en el real situado conllevaba el despliegue de negocios, pactos y tensiones en los intersticios de la institucionalidad formalmente reconocida: mercaderes, grandes comerciantes, oficiales reales, militares de alto rango, instituciones eclesiásticas y gobernadores encontraban en el situado una vía posible para captar fondos del erario con los cuales desplegar prácticas comerciales y financieras, razón por la cual el mecanismo

9 Aquellas que contasen con receptoría y tesorería, como las de Buenos Aires, La Paz, La Plata, Cochabamba, Salta, Paraguay, Córdoba y Potosí.

Io Las cuales solo contaban con receptoría: Montevideo, Oruro, Mendoza, Maldonado, Santa Fe, Carangas y Malvinas. Véase la descripción elaborada por un equipo interdisciplinario en el Departamento de Documentos Escritos, cuyo coordinador es el licenciado Gabriel Darío Taruselli, para el Censo-Guía de Archivos de España e Iberoamérica, Ministerio de Educación, Cultura y Deporte del Gobierno de España, censoarchivos.mcu.es/CensoGuia/fondoDetail.htm?id=1373934. 
de remisiones hacía confluir a los intereses lucrativos de estos actores con los intereses defensivos de la Corona ${ }^{\mathrm{II}}$. Con ello, la intervención de estos actores condicionaba el funcionamiento del situado, a la vez que expresaba la capacidad de las oligarquías locales para participar en los términos con los que se desenvolvía la fiscalidad regia en los territorios americanos ${ }^{12}$. Esta tácita negociación en la arena fiscal sobreviviría a los Habsburgo y habría de expresarse mediante una maquinaria fiscal de base redistributiva que matizaba las virtudes centralizadoras tradicionalmente atribuidas al reformismo borbónico ${ }^{13}$. El traslado de los sueldos de las tropas desde Potosí al puerto bonaerense tomaba rutas que atravesaban mercados como los de Jujuy, Salta, Tucumán, Santiago del Estero o Córdoba, y sus diversas ramificaciones yuxtapuestas con el rosario interregional de mercados (Wasserman, "Recursos fiscales"). Tal como lo describe Birocco, implicaba disputas entre los mercaderes porteños por la obtención del negocio de su conducción, el encubrimiento de operaciones en moneda o en mercancías detrás de la actividad de conducción (como también se señala en Wasserman, "Real situado"), y confería a los situadistas ventajas para la introducción de textiles europeos o esclavos en territorio altoperuano eludiendo los controles fiscales, o trocar moneda columnaria recibida en secas potosinas (escasa en Buenos Aires) por moneda sencilla con premio entre $3 \%$ y I5\% (como se demuestra en Wasserman, "Recursos fiscales"). Para el acceso a la condición de situadista, por lo tanto, los oficiales reales de Potosí recibían sobornos y regalías que agilizaban los trámites de la asignación con patrimonio deducido de la misma remuneración de soldados y oficiales (Birocco I24).

Hasta I63I, la defensa militar del puerto se encontraba a cargo de una milicia de vecinos, capitaneada por el gobernador o su teniente (o en su defecto por el alcalde de primer voto) y compuesta por cuatro compañías de a caballo con lanzas y adargas más dos compañías de infantería. Un pequeño fuerte,

II Estudios de caso pueden verse en Birocco; Saguier; Wasserman, "Real situado", "Los nombres". Para otras latitudes, véase Bertrand et al; Solbes; Solbes et al. Esta participación de los intereses de grupos dominantes americanos en la órbita fiscal se encuadra en una estructura imperial apuntalada en buena medida sobre la negociación con las oligarquías locales, tal como puede observarse en Amadori; Bertrand; Yun.

I2 Con ello, habrían de atenuarse a un mismo tiempo los contrastes que el nuevo institucionalismo económico identificaba entre el sistema fiscal español y el angloamericano, con implicancias sobre el rol asignado a dichos sistemas en la divergencia de largo plazo. Véase North y Weingast; North, Summerhill y Weingast.

I3 Sobre este tópico puede consultarse Grafe e Irigoin; Grieco; Sánchez, "Las reformas borbónicas"; Valle; Wayar. 
endeble y en constante reconstrucción desde al menos fines de la década de I590, sobre la boca del Riachuelo, era complementado con el fuerte amurallado construido por Hernandarias en I6I8 que ya para I623 solo era "un flaco reparo de tapias caídas" (Carbia y De Gandía 230). Recién en I63I el gobernador Pedro Esteban Dávila fundaba el presidio de Buenos Aires con una guarnición de tropas regulares, inicialmente compuesta por algo más de cincuenta soldados reclutados, y reconstruía el fuerte de San Baltasar de Austria. La fortaleza experimentaría modificaciones y mejoras con el gobierno de José Martínez de Salazar desde I663, en tanto que las tropas incrementarían sus filas a lo largo del siglo, ascendiendo a 300 en 1669 y a 750 en I677, para estimarse en unas 900 personas hacia I684 (Frías I23; Moutoukias, Contrabando 4I; Mörner I88-I9o). Con todo, esta guarnición militar participaba como el núcleo más numeroso del dispositivo burocrático-militar instalado en Buenos Aires por la Corona, y ello ameritaría el envío del real situado procedente de las reales cajas de Potosí, remesas de plata orientadas primordialmente a los sueldos de la tropa del presidio (Wasserman, "La necesidad").

Pesos de plata de a ocho reales

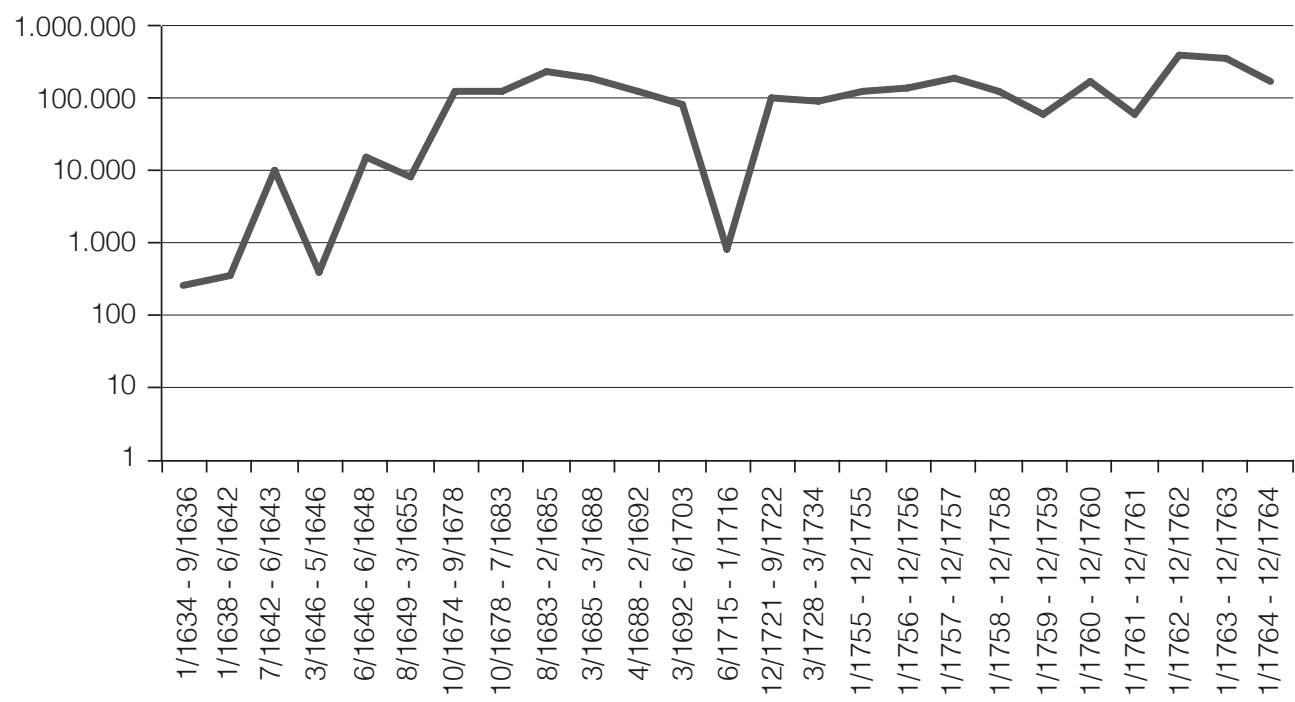

$\rightarrow$ FIGURA I.

Remesas a la Real Caja de Buenos Aires (I634-I764)

Nota: representación gráfica en escala logarítmica de base io. Las sumas son medias anuales. Fuente: elaboración propia con base en Wasserman, Las obligaciones; Klein y TePaske. Mayores precisiones sobre la evolución global de la Real Caja de Buenos Aires en Cuesta, "Impuestos imperiales". 
Si bien estas sumas representaban un bajo porcentaje de la plata quintada en Potosí durante el siglo XVII, constituían sin embargo un volumen monetario considerable en relación con las dimensiones de la población afincada en Buenos Aires (Moutoukias, Contrabando 195; Wasserman, Las obligaciones) ${ }^{14}$. Por ello, si a lo largo de todo el siglo xvir el desenvolvimiento de los intercambios interregionales hizo que el Río de la Plata y las economías regionales atrajeran "una proporción creciente de una producción decreciente de plata", para este entonces no hay una necesaria correlación entre el cambiante nivel de producción minera y metales preciosos dirigidos al Atlántico, tal como lo señala Moutoukias (Contrabando I69). Ello se constata igualmente en el progresivo crecimiento de las remesas destinadas a la Real Caja de Buenos Aires durante el siglo XviII para el mantenimiento de la guarnición militar mediante el situado potosino, tal como puede observarse en la figura I. Por su parte, la evolución de las remesas del situado se aceleraría desde la década de I760, cuando los cimientos institucionales y fiscales comenzaban a modificarse en Buenos Aires al compás de la conflictividad imperial y de su crecimiento económico (Gelman y Moraes) ${ }^{\text {Is }}$.

Las sumas anuales ingresadas por dicho concepto en la Real Caja porteńa solo atravesaron los 500.000 pesos a partir de 1767 , como respuesta a múltiples factores: la creciente conflictividad con Portugal en la frontera de Río Grande, el extrañamiento de la Compañía de Jesús, las expediciones francoespañolas a Islas Malvinas para disputar el territorio austral a Inglaterra, todo lo cual implicó la creciente gravitación de Buenos Aires como centro receptor y redistribuidor de recursos fiscales, así como el reconocimiento institucional de esa gravitación mediante la promulgación de la Contaduría Mayor de Buenos Aires

I4 Adviértase que los valores de la figura i se representan en escala logarítmica, lo que da cuenta de la amplitud del rango de sumas medias recibidas anualmente por la Real Caja de Buenos Aires de otras tesorerías de la Hacienda Real: desde los \$256,62 recibidos en promedio anualmente por la Caja entre enero de 1634 y septiembre de 1636 , hasta los $\$ 238.930,3$ recibidos en promedio anualmente entre agosto de 1683 y febrero de 1685 . A su vez, la irregularidad de los periodos fiscales registrados (estados contables que van desde los 59 días hasta los in años) hace necesario anualizar los montos recibidos para lograr una adecuada mensurabilidad. Solo se representan los periodos contables que registraron ingresos a la Real Caja de Buenos Aires procedentes de otras tesorerías.

I5 La población total estimada de Buenos Aires en 1744 alcanzaba los 11.600 habitantes, en 1778 superaba los 26.000 (alcanzaba los 37.100 al contemplar su entorno rural) y en r810 llegaba a 42.250 (92.000 si se incorpora la campaña): síntoma de crecimiento económico. Moutoukias, "El crecimiento", advierte su relación con la dinámica exportadora del puerto, aun cuando postula que la estructura sobre la que se apoyaba ese crecimiento estaba ya montada desde la década de 1730 . Sobre estos procesos, véase asimismo Gelman, "La economía”, y Santilli. 


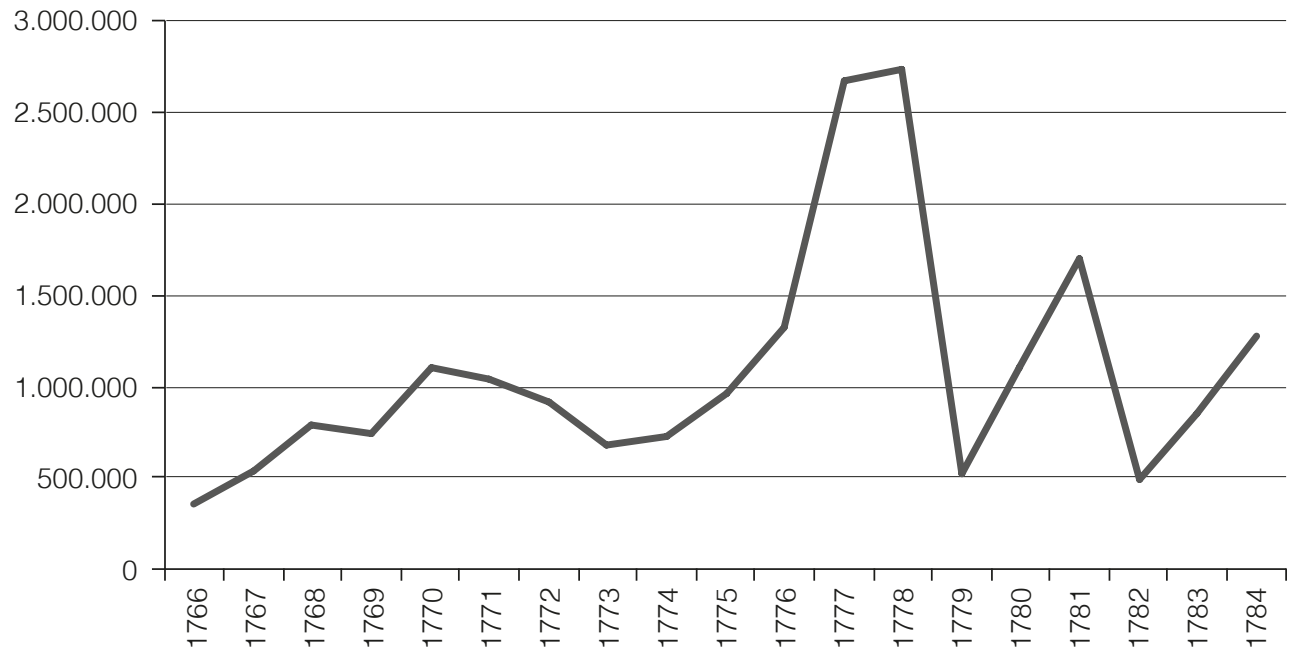

$\leftrightarrow$ FIGURA 2 .

Remesas a la Real Caja de Buenos Aires (I766-I784)

Fuente: elaboración propia con base en AGN, JSRH-RRH, XIII-42-I-20, 21, 22, 23, 24 y 25; Klein y TePaske; Cuesta, "Impuestos imperiales".

en 1767 (Wasserman, "Recursos fiscales"). Los recursos del situado continuarían retroalimentando las modulaciones del aparato defensivo bonaerense: ante la amenaza del avance portugués, las remesas enviadas anualmente al ramo de situados pasaron casi a duplicarse a partir de I776, y cuando en I777 la armada de Cevallos requiriese el aporte de unos tres millones de pesos (Cuesta, Precios 195), los ingresos del situado de Buenos Aires ascenderían a 2.674.084,8 pesos (figura 2). El situado de Buenos Aires incrementaba sideralmente sus fondos y superaba las sumas que recibían otras plazas fuertes neurálgicas, como La Habana. Así, la conflictividad con Portugal en el Río de la Plata fue a la tendencia del situado lo que la toma británica de La Habana a estas plazas del Caribe ${ }^{16}$.

16 En las décadas de 1760 y 1770 , La Habana era receptora de un promedio anual de \$1.900.000 por vía de situados y envíos extraordinarios procedentes de Nueva España y oficiaba como plaza redistribuidora hacia otros puntos del Caribe y Centroamérica (Marichal y Souto 73, 80). Todas las plazas americanas con posiciones estratégicas para la defensa del imperio participaron de una tendencia general en la amplificación de las remisiones de caudales, iniciada a comienzos de la década de 1760 y particularmente luego de la toma de La Habana por Gran Bretaña. Fue el caso de San Juan de Puerto Rico, que pasó de recibir cerca de $\$ 150.000$ en 1763 a unos $\$ 750.000$ en 1778 , en una tendencia creciente anualmente, o Cartagena, que pasó de recibir anualmente cerca de \$168.000 entre 1756-1760 a unos \$242.000 anuales entre 176I-1765 (Meisel 207; Pacheco 130 y ss.). 
De tal manera, el segundo salto cuantitativo que experimentó el cargo del ramo del situado en Buenos Aires, durante la segunda mitad de la década de I770, respondió nuevamente a la conjugación entre la gravitación del Río de la Plata como nervio sensible a la integridad del imperio y sus concomitantes reconfiguraciones institucionales.

De manera paralela, durante dicho periodo el real situado incrementó radicalmente su participación porcentual en los ingresos totales de la Real Caja de Buenos Aires (Cuesta, Precios 194 y ss.) (aun cuando todavía no absorbiera la mayor parte de los ingresos de la caja potosina, como lo haría posteriormente ${ }^{17}$, mientras la ciudad pasó a constituirse en sede de una nueva configuración política y jurisdiccional.

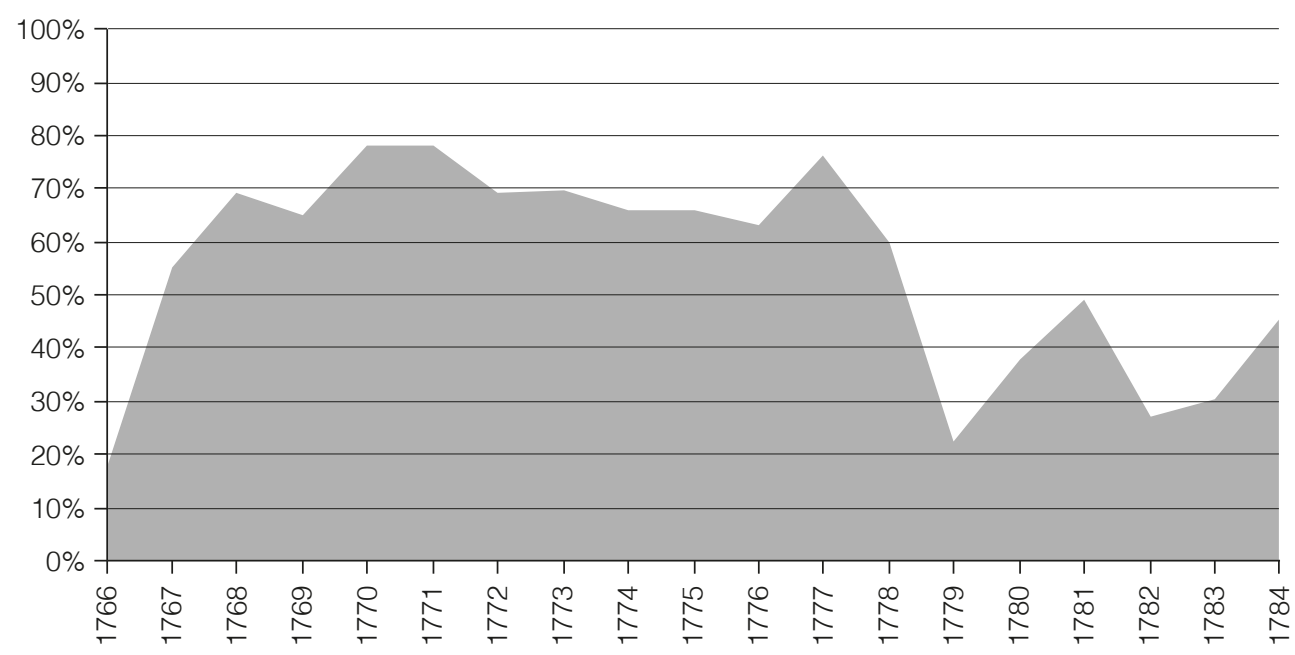

- FIGURA 3

Participación del real situado en el cargo total de la Real Caja de Buenos Aires, $1766-1784$

Nota: para la estimación porcentual se ha relacionado al cargo efectivamente reportado por los "Libros principales de cargo y data del ramo", con el cargo anual total de la Real Caja reportado por las cartas-cuentas. Dada la inexistencia del libro del ramo de situados para I779, dicha relación se estableció solo a partir de la información aportada por las cartas-cuenta. Para una aproximación a esta información desde una perspectiva global de la Real Caja de Buenos Aires, véase Cuesta, "Impuestos imperiales".

Fuente: elaboración propia con base en AGN, JSRH-RRH, XIII-42-I-20, 2I, 22, 23, 24 y 25; Klein y TePaske.

I7 Tandeter, "El eje" (199-20I), recuerda que en los años I79I-I795 las remesas de Potosí a Buenos Aires representaron el 75,80\% de los ingresos de la Villa Imperial, en tanto que esa participación se mantuvo en 64,10\% durante 1796-1800. 
El protagonismo del real situado en los ingresos totales (o cargo) de la Real Caja porteña es insoslayable. Entre 1766 y 1784 promedió el $55 \%$ de los ingresos totales a la caja porteña, y rozó el $80 \%$ de estos en algunos ańos ${ }^{18}$ (figura 3). Puede advertirse por lo tanto que estos desembolsos posibilitaron el despliegue económico de Buenos Aires al garantizar su defensa y pervivencia en el mapa imperial, volviendo con ello plausible y viable al nuevo virreinato rioplatense ${ }^{19}$. Motivado por las urgencias defensivas del estuario del río de la Plata, este sustancial incremento en la llegada de remesas fiscales a Buenos Aires, procedentes en su mayoría de las reales cajas de Potosí (Wasserman, "Recursos fiscales"), implicó tensiones en el seno de la Real Hacienda, toda vez que eran correlato y expresión de su reformulación institucional y del reposicionamiento de Buenos Aires en su esquema regional.

Un documento elaborado por los oficiales de la Real Hacienda en Buenos Aires expresa tanto aquellas reformulaciones como las tensiones que estas provocaron en torno al real situado. Asimismo, permite decodificar algunas de las razones por las cuales los intereses de actores económicos porteños confluían con el interés defensivo de la Corona.

Desde 1768 — una vez instituida la Contaduría Mayor de Buenos Airesy hasta 1777 — cuando se estableció definitivamente el Virreinato del Río de la Plata-, los oficiales reales de Buenos Aires confeccionaron un libro en el que registraron los ajustes remitidos al virrey de Lima "del haber que corresponde a las tropas veteranas y provinciales, embarcaciones de SM, gastos de provisión y demás que se ofrecen en esta Provincia de Buenos Ayres, anualmente" (AgN, $J S R H-R R H$, XIII-42-OI-I9), erogaciones que debían saldarse con las remesas de caudales procedentes de las cajas de la Villa Imperial de Potosí en concepto de real situado. Con ello, este libro de ajustes proporciona una relación anual

I8 Posteriormente, y tal como lo explica Cuesta, "Impuestos imperiales" (47), entre 1776 y 1778 los envíos del real situado habrían sobrepasado el $90 \%$ de los ingresos.

I9 Si se consideran el Regimiento de Infantería de Mallorca, el Batallón de Voluntarios de Cataluña, el Batallón de la Tropa Antigua, el Batallón Moderno de Buenos Aires, las tres compañías del Batallón de Santa Fe, el Regimiento de Dragones y la Compañía del Real Cuerpo de Artillería, los cuerpos veteranos en Buenos Aires ascendían en 177I, por caso, a unos 3.100 efectivos. A estos habría que sumar cerca de unas 200 personas enlistadas como blandengues (los cuales pasarían a transformarse en un cuerpo veterano de caballería en 1784 ). Pero las milicias en la ciudad y en la campaña bonaerense reportaban unos 5.300 hombres, junto a los cuales podrían considerarse los más de 3.000 efectivos dispuestos en las milicias de Santa Fe, Corrientes y distintos puntos de la banda oriental del río, como Montevideo o Santo Domingo Soriano (Alemano; Beverina; Wasserman, "Recursos fiscales"). 
de los gastos devengados localmente y de las sumas que en consecuencia se requerían del real situado para saldarlos: los gastos anualmente devengados eran reunidos en un "resumen general" que constituía un "presupuesto" para formular el cálculo del monto que habría de requerirse para saldar esas erogaciones al año contable vencido, en tanto que los gastos devengados se presupuestaban en el déficit del situado que habría de llegar el año siguiente (Birolo 20I). En palabras del factor Martín Joseph de Altolaguirre (quien desde 1767 obraba como oficial real en la Caja de Buenos Aires junto al contador Juan de Bustinaga y el tesorero Pedro de Medrano), cada resumen constituye "el estado que ha formado esta veeduría de los caudales que son necesarios" (AGN, JSRH-RRH, XIII-42-OI-I9, ff. 4 v.-5 r., 8 r.).

Como puede advertirse en la tabla I, las dilaciones en la llegada del situado eran sistémicas: en 1770 recién llegaban a Buenos Aires caudales que respondían a los gastos de I768. En I77I ingresaron recursos que saldaban las erogaciones de 1769 . Y sucede lo mismo con el ingreso de $\mathbf{1 7 7 2}$, que responde a lo devengado en 1770. Sin embargo, a las habituales demoras en la llegada de las remesas, se adosaba una insuficiencia crónica de los montos desembolsados en relación con los devengados ${ }^{20}$.

La acostumbrada irregularidad en los registros contables condujo a los oficiales reales de Buenos Aires a generar resúmenes generales de los gastos devengados únicamente durante los años de 1767, I768, I769, I770, I771 y I773 (de modo que los restantes ańos abarcados por el libro de ajustes solo cuentan con una razón de los situados recibidos, pero no de los gastos devengados).

Si se toman aquellos ańos durante los cuales el libro de ajustes ofrece un detalle de las sumas devengadas, y si se cotejan dichas erogaciones con los caudales efectivamente ingresados como remesas del situado (tal como fueron registrados cronológicamente y de manera desagregada en las partidas de cargo del "Libro principal de cargo y data del ramo de situados" de Buenos Aires elaborado por los oficiales reales porteños), es visible la insuficiencia de las remesas para cubrir los gastos devengados (figura 4). En suma, tanto en relación con los

20 La demora en la llegada del situado se constata desde el siglo XviI (Moutoukias, Contrabando; Saguier; Wasserman, "Real situado"). A comienzos del siglo Xviri la guarnición del presidio estaba verdaderamente empeñada: en 1705 , cuando llegó a Buenos Aires la primera remesa en varios años, las tropas estaban alcanzadas en 150.000 pesos por el abasto de alimento acumulado durante 27 meses y por gastos implicados en el vestuario para las ocho compañías acantonadas en el fuerte (Birocco). 
ingresos de remesas llegadas durante el mismo año, como con los ingresos de caudales del año siguiente, los gastos devengados no lograban ser cubiertos en su totalidad por las remisiones del real situado que debían saldarlos.

$\rightarrow$ TABLA I.

Sumas devengadas y morosidad. "Libro resumen de ajustes a las tropas, embarcaciones de su majestad y gastos. Razón de los situados recibidos de Potosí" (Buenos Aires, I768-I777)*

\begin{tabular}{|c|c|c|c|c|}
\hline Año & $\begin{array}{c}\text { Fondos del } \\
\text { situado ingresado } \\
\text { efectivamente durante } \\
\text { el año en curso }\end{array}$ & $\begin{array}{l}\text { Sumas } \\
\text { devengadas } \\
\text { durante el } \\
\text { año }\end{array}$ & $\begin{array}{l}\text { Situado ingresado } \\
\text { ese año corresponde } \\
\text { a gastos devengados } \\
\text { en }\end{array}$ & $\begin{array}{c}\text { Mora } \\
\text { en } \\
\text { años }\end{array}$ \\
\hline 1767 & $538.555,4 \mathrm{I}$ & $\mathrm{I} .328 .834,3 \mathrm{I}$ & - & - \\
\hline 1768 & $794.806,4 \mathrm{I}$ & $1.051 .966,20$ & 1767 & I \\
\hline 1769 & $744.192,97$ & $1.263 .000,22$ & 1768 & I \\
\hline 1770 & I.099.255,6I & I.160.386,54 & 1768 & 2 \\
\hline 1771 & I.039.701,19 & I.160.860,54 & 1769 & 2 \\
\hline 1772 & $912.432,10$ & - & 1770 & 2 \\
\hline 1773 & $682.142,3 \mathrm{I}$ & 852.799 & 1772 & I \\
\hline I774 & $726.244,50$ & - & I773 & I \\
\hline 1775 & $962.87 \mathrm{I}, 06$ & - & I774 & I \\
\hline 1776 & I. 331.425 & - & 1775 & I \\
\hline 1777 & $2.678 .313,17$ & - & 1776 & I \\
\hline
\end{tabular}

* Los fondos del situado ingresado efectivamente durante el año en curso son tomados de los "Libros principales de cargo y data del ramo de situados" de Buenos Aires (AGN, JSRH-RRH, XIII-42-I-2O, 2I, 22, 23, 24, 25), en tanto que las sumas devengadas durante el año provienen del "Libro resumen de ajuste a las tropas" (AGN, JSRH-RRH, XIII-42-OI-I9).

Fuente: elaboración propia con base en AGN, JSRH-RRH, XIII-42-OI-I9. 


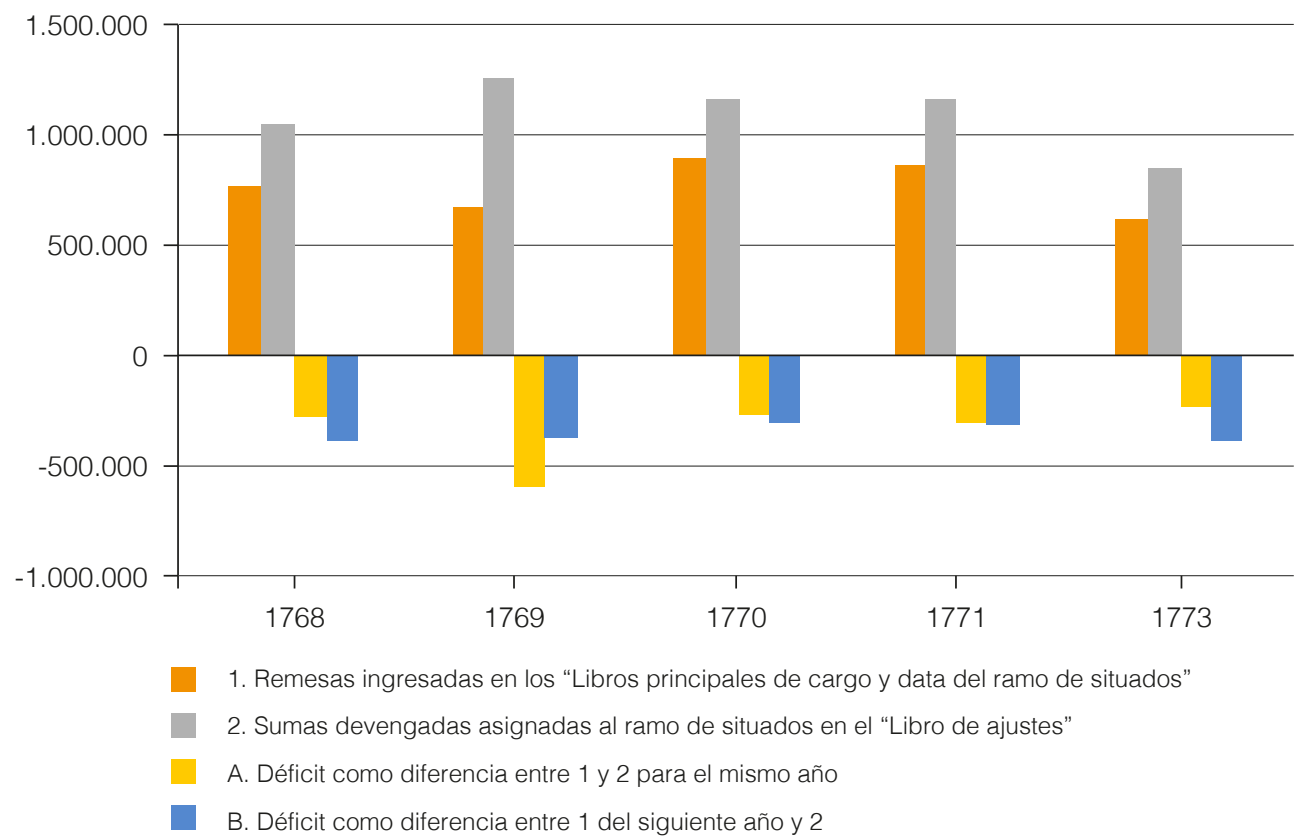

$\rightarrow$ FIGURA 4 .

Relación entre sumas devengadas y caudales ingresados por concepto de real situado

Fuente: elaboración propia con base en AGN, JSRH-RRH, XIII-42-OI-I9, 2O, 2I, 22, 23, 24 y 25.

\section{Los recursos del situado como disputa por la centralidad institucional}

La urgente cobertura del déficit resultante en el real situado abría un campo para las tensiones y las negociaciones en la Real Hacienda, así como para la participación lucrativa de diversos actores económicos de Buenos Aires.

Las pujas entre las distintas administraciones regionales de la Real Hacienda quedaban testimoniadas en el libro de ajustes, esquirla documental de este proceso de reconfiguraciones institucionales en el cual la jerarquía jurisdiccional de Buenos Aires en la Real Hacienda ascendía, sin dejar de depender aún de las autorizaciones expedidas en Lima. Así, las tensiones comenzaban a expresarse cuando el factor don Martín Joseph de Altolaguirre, el tesorero don Pedro Medrano y el contador don Juan de Bustinaga, oficiales reales bonaerenses, enviaron el resumen general sobre los gastos devengados en 1768 , en el que 
se computan los fondos necesarios para "la paga de la tropa que sirbe al Rey en esta provincia, compra de viveres para su manutencion, gastos que ocasionan las embarcaciones de guerra, nuebos establecimientos de las Islas Malvinas, Tierra del Fuego y las demas urgencias". En esa ocasión, el is de enero de 1769 los oficiales adjuntaron una misiva al virrey Manuel de Amat en la que declaraban que al I.05I.966,2 pesos “yndispensables para el año" debería agregarse, de manera extraordinaria, la suma de 457.780,2 pesos "que se estan debiendo a las tropas y proveedor de viveres" (AGN, JSRH-RRH, XIII-42-OI-I9, ff. 4 V.-5 v. $)^{21}$. El atraso acumulado y el consecuente pedido extraordinario, señalaban, "desde luego no resultara si los 707.337 pesos que restan remitir por los oficiales reales de Potosy para el completo de I.328.837 pesos que se consideraron necesarios hubiesen venido a tiempo" (AGN, JSRH-RRH, XIII-42-OI-I9, ff. 4 v.-5 v. Énfasis con cursiva añadido). Y dichos caudales retrasados, proseguían,

aun todavia seria preciso viniesen yntegramente, a no haver tomado el advitrio de retener en estas Reales Caxas mas de 200.000 pesos de los derechos de Yndulto y Guardacostas, que en Cadiz devian exigir los caudales registrados en los navios que han salido de este Rio, con cuia suma en parte se ha remediado aquella falta. (AGN, JSRH-RRH, XIII-42-OI-I9, ff. 4 v.-5 v.)

La autonomía ejercida en la toma de determinaciones por parte de los oficiales reales de Buenos Aires quedaba entonces justificada por las faltas cometidas por los oficiales de la Hacienda en Potosí: la retención en el Río de la Plata de recursos que debían liquidarse en Cádiz resultaba necesaria para subsanar las demoras de los caudales ante las urgencias de la coyuntura. En este sentido, los oficiales reales de Buenos Aires contaban con el respaldo del gobernador del Río de la Plata, quien por ordenanza real del 17 de enero de 1768 había dispuesto que "para las prontas urgencias se retengan acá los derechos de Yndultos y Guarda Costas; luego que venga el situado de Potosi se remita a España la cantidad que se debiere reintegrar por esta razon". Por tal motivo, junto al ejercicio de

2 En términos normativos, para el periodo que estamos abordando y hasta al menos I774, la suma fija convenida como fondos del situado que debía enviarse a Buenos Aires ascendía a 550.000 pesos en plata doble. Sin embargo, en febrero de 1775 se disponía que el real situado a Buenos Aires ascendiese a 900.000 pesos. Entre tanto, por Real Orden del 8 de abril de 1776 se sistematizaba la regularidad de un socorro extraordinario anual en 500.000 pesos, que junto a los del situado ascendían a I.400.000 pesos que debían llegar anualmente a Buenos Aires (Wasserman, "Recursos fiscales"). 
su autonomía para imponer prioridades sobre el gasto, los oficiales reales de la tesorería porteńa no dejaban de contar con argumentos para insistir en que "rigurosamente debia benir toda la suma" del situado desde Potosí.

La creciente autonomía de los oficiales reales de Buenos Aires en la política de asignación de recursos fiscales se apuntalaba así en la argumentada ineficiencia del sistema de remisiones. Por su parte, la retención de los derechos de indultos y guardacostas estaba entre tanto justificada por la exigüidad de las bases imponibles locales. Así, no podían tampoco echar mano de otros ramos fiscales para enviar los dineros adeudados a Cádiz, pues

aunque quisieramos esforzarnos a efectuar esto ultimo con el producto de los demas ramos que se administran en estas Reales Caxas, es muy corto su ymporte respecto de las pensiones que sobre sí tienen, como son los sueldos del Governador de esta Provincia, de los de Montevideo y Paraguay y de diferentes ministros, empleados y ocupados en el Real Servicio, las obras de fortificacion en varios puestos de la provincia, los crecidos gastos que ocasionan mas de doce embarcaciones que zelan el comercio ilicito en este Rio y en otros muchos objetos del Real Servicio, que por no cansar la atencion de VE dejamos de referir; que las mas veces lejos de tener ningun sobrante, se hallan alcanzados los mismos ramos, maiormente ahora que ya no se exije de los caudales que se embarcan a España el derecho de Aduana, por haverlo asi dispuesto SM en su Real Cedula su fecha Io de marzo de I767. (AGN, JSRH-RRH, XIII-42-OI-I9, ff. 4 v.-5 v. Énfasis con cursiva añadido)

Mal podrían pedir las autoridades virreinales del Perú a los oficiales del erario regio en Buenos Aires que transfiriesen ingresos procedentes de los ramos particulares de la Real Hacienda ${ }^{22}$ y ramos particulares ajenos ${ }^{23}$ hacia los ramos de la Real Hacienda en común o masa común (con cuyos recursos debían afrontarse los gastos generales corrientes), para engrosar la disponibilidad de fondos aplicables a erogaciones locales (Amaral, "Las finanzas"; "Seguridad"). Si bien la cobertura de los gastos corrientes mediante la apelación a recursos procedentes de rubros particulares y ajenos era una práctica incorporada sistemáticamente por los oficiales

22 Fondos pertenecientes a la Corona, con destino predeterminado por disposiciones que definían su aplicación a finalidades específicas.

23 Fondos de terceros custodiados por la Real Caja pero no pertenecientes a la Real Hacienda, recaudados para fines señalados. 
de la Real Caja de Buenos Aires para financiar el déficit fiscal de corto plazo, la normativa hacendaria no contemplaba la cobertura de gastos corrientes mediante el empleo de fondos que no podían ser distribuidos localmente. La contradicción entre la acelerada velocidad de las erogaciones en Buenos Aires y la demora en la llegada del situado, difícilmente podría llevar al virrey del Perú a reconocer como legítima esta práctica contravencional para financiar el déficit local. Antes bien, debería equiparar la velocidad del envío de remesas a Buenos Aires a la velocidad de las erogaciones rioplatenses, para bien del real servicio.

Los oficiales reales de Buenos Aires, sin embargo, no detenían allí su argumentación. Tras demostrar la legitimidad de su fáctica autonomía en la política fiscal y expresar que las circunstancias les impedían recurrir a una contravencional práctica contable, manifestaban:

Y los comisos, que componian en otro tiempo el miembro mas principal, hoy se experimenta el mas debil, por la suma estrechez en que se ven los contrabandistas, sin darles lugar a que estiendan su comercio clandestino. (AGN, JSRH-RRH, XIII-42-OI-I9, ff. 4 v.-5 v.)

Jaque al virrey del Perú. La antigua estructuración institucional de la Hacienda regional, cuya reformulación comenzaba a advertirse, había sido fomentada y estimulada por los intereses monopolistas del comercio limeño, que encontraban en Buenos Aires una competencia indeseable en el marco de la Carrera de Indias y lograron desde fines del siglo xvi circunscribir el comercio legal porteño a unos muy exiguos cauces permitidos por la Corona ${ }^{24}$.

24 El 28 de enero de 1594, como respuesta al descontento del comercio limeño, el rey emitía una real cédula mediante la cual prohibía que por el Río de la Plata "se meta ni se contrate esclauos ni otro ningún genero de mercadurias del brasil angola guinea ni otra ninguna parte de la corona de portugal ni yndias orientales sino fuere de sebilla en navios despachados por la casa de la contratacion" (citado en Levillier 237). Solo los navíos sevillanos con licencia especial para comunicar directamente a España con el Río de la Plata protagonizarían un tráfico legítimo. El 20 de agosto de 1602 la Corona otorgaba por real cédula a los vecinos de Buenos Aires una merced en que se les concedía una autorización por plazo de seis años para exportar a Brasil y Guinea, anualmente y en navíos propios, 2.000 fanegas de harina, 500 quintales de cecina y 500 arrobas de sebo, en tanto que se prohibía la exportación de plata. A ello le correspondía el permiso para importar, como retorno, "lienço calçado y otras cosas semejantes y fierro y açero". La importación de esclavos quedaba vedada. También se prohibía el ingreso o egreso por Buenos Aires de toda persona libre carente de licencia real para ello. A su vez, las importaciones debían consumirse en el Río de la Plata y debía evitarse que este fuese un puerto del interior para la salida de metálico. Los intereses del comercio limeño estaban presentes en tales mercedes, ya que exportación de plata e importación de esclavos constituían las dos caras de una misma moneda. Finalizada la renovación de las mercedes, desde 
Así, la capacidad de financiamiento del aparato defensivo y gubernamental de Buenos Aires se había sostenido, al menos en parte, sobre la fiscalización de partidas ingresadas ilegalmente: los comisos reportaban ingresos (magros) a la Real Caja de Buenos Aires, a la vez que resultaban la instancia propicia para legalizar esclavos o efectos introducidos ilegalmente por comerciantes en connivencia con los oficiales reales porteños. De este modo, para sostener el balance con el poderoso cuerpo comercial limeño, la Corona solo podía lograr que su estructura de poder en Buenos Aires se financiase a pesar de sus propias leyes, mediante una "transgresión legal a las leyes" que reportase a los actores locales unos ingresos necesarios para sostener al puerto, pero que la propia Corona había prohibido en concordancia con los intereses del comercio de Lima (Moutoukias, "Power" 799-800). Ahora, en 1769, los oficiales reales de Buenos Aires mostraban al virrey del Perú que el cumplimiento sostenido de las medidas prohibitivas exigidas por el comercio de Lima había ahogado una base imponible local crítica para la defensa imperial, y que el costo de ese cumplimiento se traducía como la efusión de recursos fiscales peruanos hacia Buenos Aires por vía del real situado. Si la remisión de caudales a Buenos Aires para las urgencias del real servicio constituía la contracara de la estructura hacendaria impuesta por los intereses peruanos, sostener la irregularidad en los envíos equivaldría a renegar de aquella estructura hacendaria vigente desde hacía más de un siglo y medio. Poco margen de maniobra le quedaba al virrey:

Esperamos del acreditado zelo de VE que atendiendo a estas poderosas razones se servira estrechar sus providencias, con el fin de que se logre vengan los caudales necesarios para atender a objetos tan ymportantes como son los que oy dia ocupan la atencion de SM en esta dilatada provincia. Nuestro Señor guarde a VE muchos años. (AGN, XIII, JSRH-RRH, XIII-42-OI-I9, ff. 4 V.-5 v.)

La situación se repetiría con una frecuencia recurrente. Ante la llegada del situado en I77I, que venía a cubrir erogaciones devengadas desde I769 "para la satisfaccion de los sueldos de oficiales, tropas y demas gastos urgentes",

I623 se abrió el periodo de los navíos de aviso y registro, con tonelaje limitado, como los únicos legalmente aceptados para interactuar con Buenos Aires, a los que se prohibía tocar puertos brasileños a la ida e introducir extranjeros en el puerto (Jumar; Molina 219; Moutoukias, Contrabando $77,93)$. Desde entonces, los navíos con licencia de la Corona o navíos sueltos serían el único cauce legalmente permitido para el comercio de Buenos Aires. 
los oficiales reales de Buenos Aires declaraban no solo la demora de dos años, sino un faltante de 160.975 pesos que "restan de falta a su cumplimiento", los cuales — nuevamente — "se han cubierto con las partidas de Yndulto y Guarda Costas de los remitidos de esta especie que se han detenido de orden de esta gobernación" (AGN, JSRH-RRH, XIII-42-OI-I9, ff. 8 r.-9 v.). Entre tanto, en 1772 los caudales remitidos volvían a ser inferiores a los gastos efectuados, y en esta ocasión el déficit del situado se resolvía apelando a otro ramo fiscal, pues ese año las erogaciones "en parte se han suplido con los sobrantes de Desertores" (AGN, JSRH-RRH, XIII-42-OI-I9, ff. 9 r.-9 v.).

En efecto, durante 1772 el real situado echaría mano no solo de otros ramos como el de desertores (compuesto del reintegro por sueldos no devengados por la creciente deserción de soldados), sino también de un ramo que expresa el reposicionamiento central de la Real Hacienda de Buenos Aires: el ramo de guerra. Creado en 1752 por el Cabildo de Buenos Aires, el ramo de guerra procuraba recaudar fondos gravando el comercio exterior de cueros y la introducción de acero y hierro a las provincias, para sostener con esos recursos a tres compañías de blandengues destinadas por el cuerpo capitular a la atención de la frontera indigena bonaerense. La insuficiencia de la recaudación y el resultante endeudamiento con las milicias sirvió como argumento para que en $176 \mathrm{I}$ el ramo de guerra fuese quitado de la órbita del Cabildo y pasase a ser competencia de la Real Hacienda. El avance del erario regio local sobre esa estructura fiscal municipal implicó, en un comienzo, el aporte de fondos del situado para cubrir las deudas con las compañías de frontera (como sucedió en i762, cuando se liberaron fondos del situado para el ramo de guerra, con cargo de reintegro). Sin embargo, desde 1772 el ramo de guerra dejó de ser deficitario para ser superavitario, lo cual permitió a los oficiales reales desviar fondos asignados a la defensa de la frontera indígena para aplicarlos a la financiación de un situado que debería solventar los demás gastos militares (Alemano).

En 1773 el ramo de situados de Buenos Aires volvía a estar "alcanzado" - es decir, deficitario - por el desequilibrio entre erogaciones devengadas e ingresos, por lo cual el 3I de diciembre de dicho ańo los oficiales enfatizaban que la causa de resultar el antezedente alcanze, y el que aparece de los demas ańos antezedentes, es porque los embios de caudales han sido en menos cantidad que los gastos que en cada año se han verificado, de que rezultan los alcanzes que en el dia haze la tropa, marina y demas interesados acreedores. (AGN, JSRH-RRH, XIII-42-OI-I9, ff. IO r.-IO v.) 
De este modo, los oficiales reales de Buenos Aires procuraban cubrir el déficit del ramo de situados mediante distintas estrategias, como la retención en el Río de la Plata de derechos que debían liquidarse en Cádiz, o el recurso a fondos procedentes de ramos fiscales asignados a otras finalidades. Sin embargo, y volviendo sobre las palabras de los propios oficiales reales, debe advertirse que este recurso a estrategias alternativas era empleado en la medida en que la Real Hacienda estaba "debiendo a las tropas y proveedor de viveres", o a "la tropa, marina y demás interesados acreedores”.

Era una multitud de deudas con una heterogeneidad de actores locales y regionales la que permitía a la Real Hacienda en Buenos Aires sostener el aparato defensivo en los hechos; los caudales habrían de reintegrarlas. El ramo de situados era un ramo alcanzado, y sus deudas eran las que lo sostenían en el corto plazo ${ }^{25}$.

\section{Acreedores de la Real Hacienda: el situado como campo de inversión}

Si la cobertura del déficit en el ramo de situados generaba tensiones y negociaciones entre las bases regionales de la Real Hacienda, también ofrecía la participación de diversos actores económicos de Buenos Aires mediante prácticas crediticias. Desde el siglo xvir, los retrasos y la irregularidad en la llegada de estos recursos a Buenos Aires constituían la ocasión para que comerciantes y militares de altos rangos en coalición con aquellos anticipasen, a crédito y precios inflados, los bienes y servicios necesarios para una tropa desprovista de ingresos ${ }^{26}$.

25 Sobre los erarios alcanzados — deficitarios — véase Sánchez, "A la búsqueda".

26 En este sentido, ya desde 1678 se encuentran cesiones de deuda entre miembros de la guarnición, como la que realizó el capitán Andrés Corvalán a favor del ayudante del presidio, Francisco de la Cámara, por 255 pesos que debían cobrarse de la Real Caja "en el pagamento general primero siguiente que se a de hazer al Presidio, los quales se me deben del sueldo de capitan de Infanteria y de reformado del enfermo en dicho Presidio, como constara de las listas reales a que me refiero". Lo anterior, por cuanto Francisco de la Cámara había anticipado los 255 pesos a Corvalán para realizar su viaje a Chile (AGN, ER-EA, IX-3965, ff. 342 r.-342 v., I2 de octubre de I678). En esta misma tónica, el I. ${ }^{\circ}$ de diciembre de 1679 Francisco de Fuentes cedía al sargento mayor Juan Pacheco de Santa Cruz el derecho a cobrar 84 pesos de la Caja Real "que se me restan deviendo del sueldo que devengue de la plasa que servi en el Presidio deste puerto" (AGN, ER-EA, IX-3966, ff. 27I r.-27I v.). Francisco de la Cámara y Juan Pacheco de Santa Cruz eran, en efecto, proveedores y acreedores habituales de la guarnición del presidio y en algunas ocasiones se embolsaron con un 1o \% de sobreprecio, en connivencia 
Incluso los mismos gobernadores rioplatenses participaban desde temprano en este negocio local, no solo como vértices ocluidos de las redes de comercialización, sino, asimismo, como acreedores directos de los soldados del presidio de Buenos Aires: por caso, el gobernador Baygorri declaraba el 22 de febrero de 1658 que "algunos soldados deste presidio me deben algunas cantidades de dinero que les he prestado" (AGN, ER-EA, IX-3956, ff. 455 r.-456 v.).

Así, con la llegada de las remesas monetarias a Buenos Aires, la real caja local direccionaba el pago en moneda a dichos acreedores en calidad de reintegro y les permitía el embolso de metálico que más difícilmente hubiesen obtenido a través de la oferta de los mismos bienes en sus tiendas (Birocco; Gelman, "El gran comerciante" 492; Moutoukias, "Power" 787-788; Saguier; Wasserman, "Recursos fiscales"). Puesto que los caudales del real situado llegaban a Buenos Aires en moneda de plata doble, la caja de dicha ciudad contaba con la posibilidad de obtener el premio de su cambio a moneda de plata corriente o sencilla ${ }^{27}$, la cual se vendía a una tasa flotante del $4 \%$ al $6 \%$ y, desde 1768 , regulada en $3 \%$ (Wasserman, "Recursos fiscales"). La apreciación diferenciada resultaba así de la presión que sobre la demanda de las monedas fuertes ejercía el gran comercio, antes que de diferencias entre el fino, la ley o el peso de la pieza (Saguier) ${ }^{28}$. Entonces, el comercio y la transferencia de recursos fiscales se enlazaban a partir de la coexistencia de distintos niveles monetarios, por mano de grandes comerciantes que compraban en la Real Caja moneda doble para su empleo en las transacciones de larga distancia (Wasserman, "Recursos fiscales"). Los acreedores locales eran, desde luego, los principales captadores de moneda doble procedente del situado.

con el gobernador, tal como sucedía con la red estructurada entre Juan Pacheco de Santa Cruz, Amador de Roxas y Azevedo y el gobernador Andrés de Robles, acusados de concertar una compañía para tal fin (Moutoukias, Contrabando 194; Wasserman, Las obligaciones).

27 Tándeter, "El papel”, explicó la distinción entre niveles superiores e inferiores de la circulación monetaria en América, en función de la sobrevaloración experimentada por las monedas potosinas de mayor denominación a partir de su aceptación exclusiva por parte de comerciantes ultramarinos. Una sobrevaloración que tomaba forma en el premio de estas monedas dobles ofuertes sobre monedas de baja denominación, sencillas o corrientes, relegadas a circuitos internos. Las monedas dobles, con valores nominales de ocho y cuatro reales, resultaban así mejor apreciadas que las monedas sencillas, de dos reales, un real, medio real y un cuarto de real (o cuartillo).

28 El caso de Belgrano Peri, estudiado por Gelman, "El gran comerciante", permite comprender que el gran comerciante realizaba sus ventas a pago diferido pautando los reintegros en moneda metálica, para articular las diferencias que distintas plazas ofrecían en el premio del metálico bueno sobre el malo y amplificar ese diferencial con la remisión de la plata a Europa. 
De este modo, los sueldos de la tropa que llegaban con el real situado de Potosí se direccionaban hacia los talegos de comerciantes y funcionarios locales, a nombre de los cuales habían sido libradas fichas y vales. Comenzaba a advertirse de tal manera que el crédito de los comerciantes era el que sostenía el mantenimiento de la tropa (Moutoukias, Contrabando 194).

Sin embargo, durante el periodo de reconfiguraciones hacendísticas que aquí abordamos, estos flujos del situado ya no solo discurrían por intersticios económicos relativamente externos a la contabilidad de la Real Caja; la consolidación del aparato hacendario en Buenos Aires permitía que esos flujos fuesen crecientemente canalizados hacia los acreedores locales por canales instituidos en la Hacienda. Volviendo a los años para los cuales el libro de ajustes ofrece resúmenes generales de los gastos devengados (1767, I768, I769, I770, I77I y I773), una aproximación desagregada a las I.314 partidas de esas erogaciones, que fueron asentadas diariamente durante dichos años en el "Libro de cargo y data del ramo de situados", pone en evidencia que los pagos a acreedores y proveedores ocupaban un lugar fundamental, constituyendo el segundo renglón de desembolsos anuales después del pago de sueldos vencidos a las tropas (figura 5).

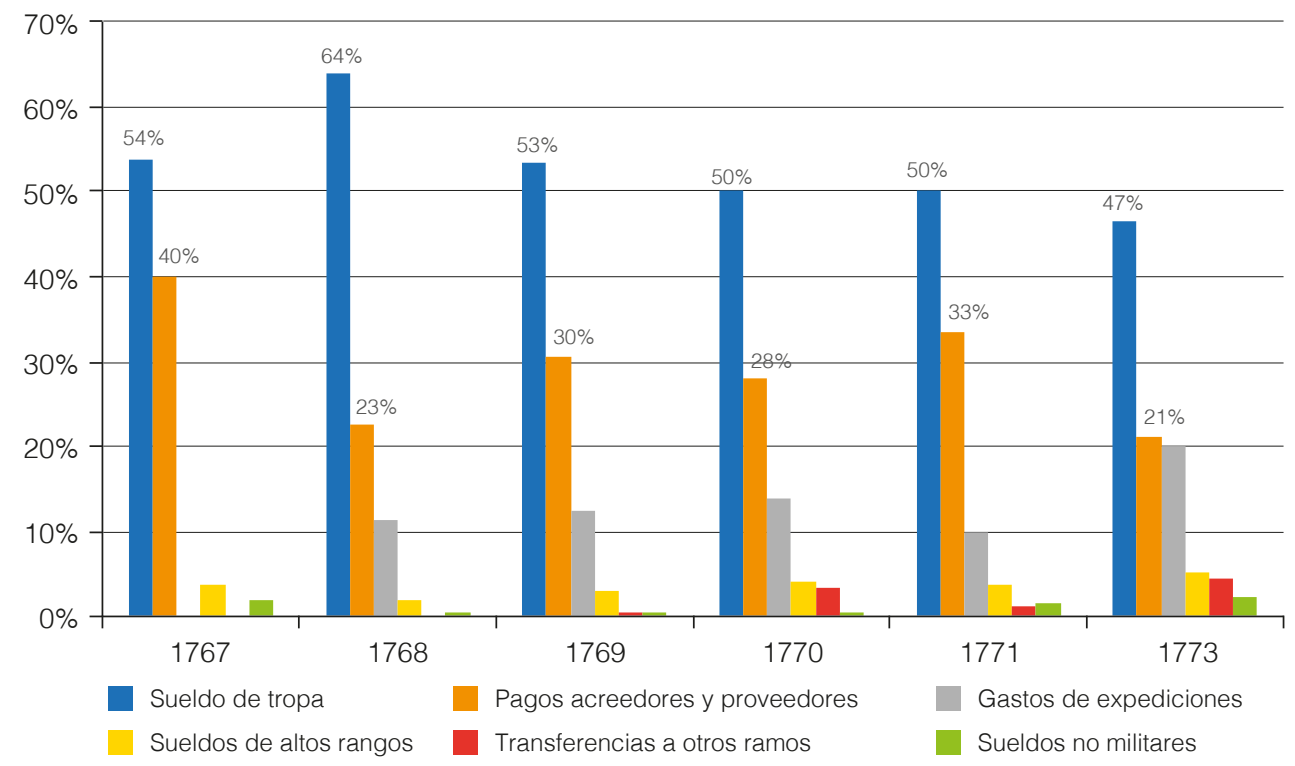

- FIGURA 5.

Composición de las erogaciones anuales del ramo de situados de Buenos Aires (años seleccionados)

Fuente: elaboración propia con base en AGN, JSRH-RRH, XIII-42-OI-2O, 2 I y 22. 
En promedio, el 31 \% de la distribución de los fondos del situado se destinaba anualmente a reintegrar créditos y anticipos a los acreedores y proveedores. Tales adelantos y suplementos eran, por lo tanto, los que permitían que las compañías de la guarnición se sostuviesen hasta la llegada de las remesas y la liquidación de los sueldos vencidos a las tropas (tabla 2). El crédito local condicionaba el funcionamiento de la defensa imperial en el estuario rioplatense.

\section{$\rightarrow$ TABLA 2.}

Conceptos anticipados a crédito, con reintegro asignado al ramo de situados de Buenos Aires (I767, I768, I769, I770, I77I y I773)

\begin{tabular}{|l|c|c|}
\multicolumn{1}{|c|}{ Concepto } & $\$$ & $\%$ \\
\hline Víveres & $552.212,49$ & $42,2 \%$ \\
\hline Suplementos monetarios & $403.184,63$ & $30,8 \%$ \\
\hline Habilitación y mantenimiento de embarcaciones & $163.954,63$ & $\mathrm{I} 2,5 \%$ \\
\hline Mantenimiento de establecimientos & $97.602,61$ & $7,5 \%$ \\
\hline Caballos, mulas, bueyes & $45.719,69$ & $3,5 \%$ \\
\hline Vestuario & $22.020,50$ & $\mathbf{1 , 7 \%}$ \\
\hline Medicamentos & $15.369,59$ & $\mathrm{I}, 2 \%$ \\
\hline Hospedaje & $5.667,53$ & $0,4 \%$ \\
\hline Armamento y pólvora & $3.272,09$ & $0,2 \%$ \\
\hline Útiles & 948,875 & $0,1 \%$ \\
\hline Total general & $\mathbf{1 . 3 0 9 . 9 5 2 , 6 3}$ & $\mathbf{1 0 0 , 0 \%}$ \\
\hline
\end{tabular}

Fuente: elaboración propia con base en AGN, JSRH-RRH, XIII-42-OI-2O, 2 I y 22.

De los 292 actores que recibieron dinero del ramo de situados por reintegros de créditos durante dichos años, el $59 \%$ estuvo concentrado en manos del guipuzcoano Martin de Sarratea, del comerciante naviero Francisco de San Ginés y del comerciante navarro Juan Ignacio de Elía, los tres asentistas de víveres del periodo ${ }^{29}$.

29 Sobre el perfil de estos asentistas, véase Wasserman, "Erogaciones fiscales”. 
En este sentido, si entre fines del siglo Xvir y comienzos del XVIII los gobernadores concedían un monopolio de hecho a distintos mercaderes para la provisión de vestuario, alimento o socorros a las tropas — que eran liquidados apelando a la circulación de vales descontables de los sueldos con la llegada del situado(Birocco), durante el periodo de reconfiguraciones que corre entre I767 y 1777 se consolidó la figura del asentista de víveres, reconocida jurídicamente por la Real Hacienda mediante contrato ${ }^{30}$. La provisión de alimento y habilitación de embarcaciones, tropas y pasajeros, en efecto, absorbía el grueso de los recursos de la Corona a escala monárquica. Y a lo largo del siglo Xvin fue la modalidad del asiento contratado con particulares, antes que la modalidad de la administración directa, la que predominó como modelo elegido por los Borbones para abastecimiento de víveres (Torres, "Administración" I88).

Desde luego, los asentistas de víveres no eran los únicos proveedores y acreedores de la Hacienda local: estaban escoltados por "individuos del comercio", quienes aún sin representación corporativa actuaban colectivamente en operaciones financieras con el erario. Así, el I. ${ }^{\circ}$ de marzo de I768, el Gobierno del Río de la Plata disponía que se pagase del ramo de situados la suma de 52.844, I pesos a "quarenta individuos de este comercio que hicieron suplemento a $\mathrm{Su}$ Majestad", en pago por "cantidades con que concurrieron para las urgencias del Real Servicio". Puntualmente, se les estaba retribuyendo, en moneda doble, por los préstamos que efectuaron en noviembre de 1767 para cubrir los gastos de la fragata Venus (que desde la ensenada de Barragán llevaría a la Península unos I50 jesuitas expulsados) y diversas erogaciones implicadas en las expediciones a Islas Malvinas (AGN, JSRH-RRH, XIII-42-I-20, f. 99 r.). El 29 de ese mismo mes, los oficiales de la Real Caja volverían a desembolsar unos 25.804,6 pesos en moneda doble a "quarenta y ocho individuos de este comercio a buena quenta de los suplementos que hicieron a Su Majestad" por el mismo concepto que en la ocasión previa (AGN, JSRH-RRH, XIII-42-I-20, f. IOO r.). De esta manera, el colectivo de comerciantes porteños recibía en 1768 la elevada suma de 78.648,7 pesos en concepto de repago por créditos otorgados a la Hacienda para la defensa.

30 Tal como lo señalase Sandrín, los asentistas de víveres desde luego no circunscribían sus actividades económicas a esa función, la cual participaba de un heterogéneo conjunto de negocios y empresas interrelacionadas de distintos modos con la provisión contractual dispuesta por el asiento (a la vez que el contrato fomentaba el despliegue de sus propias redes de transporte, entre otros negocios concatenados al suministro de víveres). 
En el pago por reintegros a acreedores desde el ramo de situados, aquellos tres asentistas de víveres y este colectivo de comerciantes porteños eran seguidos por un grupo de acreedores que hacia 1773 suplió en diversas ocasiones el abultado monto de 33.872 pesos en la Real Caja de Montevideo "para ocurrir con ellos a las urgencias del Real Servicio de dicha plaza y a las que puedan ocasionarse con motivo de la presente expedicion" (AGN, JSRH-RRH, XIII-42-I-22, f. 52 v.). El reintegro de sus suplementos era realizado en la Real Caja de Buenos Aires "en virtud de libranzas del ofizial real de Montevideo", don Joseph Francisco de Sostoa, "quien los recivio en aquella caja". Así, los acreedores recibían en Montevideo libranzas giradas contra la tesorería porteña, donde iban presentándolas a medida que se acercaban a Buenos Aires para cobrarlas del ramo de situados ${ }^{31}$.

Junto a los asentistas, comerciantes y tenedores de libranzas montevideanos, otro renglón de reintegros a acreditaciones financieras lo constituían las transferencias hacia otros ramos fiscales, que en esos años ascendieron a II5.000 pesos, expresión de aquel mecanismo de financiación interna que avanzaría con el correr del siglo xviıI (Amaral, "Las finanzas"; Amaral, "Seguridad"). Resulta destacable, sin embargo, que en todos estos casos en los que se realizaban transferencias desde el ramo de situados hacia otros ramos, la operación contable respondía a la necesidad de saldar deudas que habían sido contraídas por la Hacienda mediante el ingreso del crédito en aquellos otros ramos, y que encontraban fondos disponibles para su rembolso en este ramo de situados $^{32}$.

$3 \mathbf{I}$ Las partidas en que quedan asentados los pagos a acreedores montevideanos explican que los montos de las libranzas eran, por ejemplo, "entregados a varios individuos en los dias nuebe, diez y diez y seis del corriente mes, en virtud de libranzas del citado ofizial real don Joseph Francisto de Sostoa, quien los recivio en aquella caja para ocurrir con ellos a las urgencias del Real Servicio de dicha plaza y a las que puedan ocasionarse con motivo de la presente expedicion" (AGN, JSRH-RRH, XIII-42-I-22, f. 52 V., I6 de diciembre de 1773). Sobre el empleo de libranzas en la Hacienda Real borbónica véase Dedieu; Del Río; para su enlace con la circulación comercial, Pérez. Asumiendo junto a Dedieu que "aceptar una libranza es un acto de fe", esto es, "una operación caracterizada por un alto grado de incertidumbre”, será conveniente evaluar posteriormente en qué medida en Buenos Aires, durante dicho periodo, el circuito de libranzas emitidas por la Hacienda se circunscribió a quienes podían disminuir aquella incertidumbre apelando a recursos relacionales estratégicos, como el tesorero en cuanto que fuente informacional, o jerarquías políticas que agilizasen el cobro (Dedieu 4-5).

32 De esta manera, el 12 de marzo de 1767 se sacaban 75.000 pesos del ramo de situados, "pasados al ramo de la expedicion a las Islas Malvinas y descubrimiento de la Tierra del Fuego, para satisfacer a cinco individuos de este comercio que suplieron a $S M$ igual cantidad en los dias seis y siete de febrero proximo pasado" (AGN, JSRH-RRH, XIII-42-I-20, f. 75 r., I2 de marzo de 1767). En una misma sintonía, en mayo de 1768 se sacaban 10.000 pesos del ramo y se los traspasaban a otro "para satisfacer 
De esta manera, la Real Hacienda dependía no solo del crédito de los asentistas, sino del crédito de individuos del comercio y acreedores que aportasen suplementos monetarios de manera sistemática. A ellos se agregaría, desde luego, una extensa nómina de acreedores menores que con sus préstamos, provisiones y anticipos a las tropas sostenían y condicionaban la capacidad de la Hacienda para volver operativa la defensa del Río de la Plata, intermediando en la gestión de los recursos del real situado.

La ocasional monetización de los títulos capilarmente otorgados por el erario a sus acreedores representaba para estos, entre tanto, una herramienta con la cual dinamizar sus negocios. Por caso, en 1773 Manuel de Aldao y Breijo compraba a crédito un esclavo de Andrés del Toro, escriturando a su favor una obligación por valor de 220 pesos. La deuda sería saldada apelando a la Real Hacienda en Buenos Aires, pues Aldao y Breijo era "acrehedor de la Real Hazienda" por "importe de porcion de reces que subministró a la tropa, en tiempo de la Guerra de la Colonia", gestionados en el ramo de situados (AGN, JSRH-RRH, XIII-42-I-22, f. 38 r.). De este modo, sería la Real Caja de Buenos Aires la que pagase al vendedor, Andrés de Toro, el importe del esclavo comprado por Aldao y Breijo. El I3 de noviembre de 1773, el tesorero Pedro Medrano pagaba a Andrés de Toro 220 pesos corrientes "que le devia a este don Manuel Antonio Aldao y Breyjo, procedidos de una obligacion que a su favor otorgó por la compra de un negro llamado Pedro" (AGN, JSRH-RRH, XIII-42-I-22, f. 47 r.).

De este modo, ser "acrehedor de la Real Hazienda" por las provisiones o suplementos de dinero para sueldos a las tropas, implicaba no solo el asegurado retorno en metálico para el acreedor, sino una virtual cuenta corriente abierta que permitía lubricar los intercambios empleando los títulos del erario como medio de pago y, oportunamente, como garantía de los compromisos crediticios personales (Birocco I27). Por lo tanto, incrementar los fondos del situado direccionados hacia Buenos Aires, disminuir su irregularidad y aumentar su frecuencia, también interesaba a los comerciantes del estuario rioplatense. Siendo el aumento de estas remisiones una de las principales formas mediante las cuales se jerarquizaba a Buenos Aires en el esquema hacendario, los intereses

los creditos contrahidos contra la Real Hacienda durante el tiempo que governo esta provincia el excelentisimo señor governador don Pedro de Cevallos" (AGN, JSRH-RRH, XIII-42-I-2O, f. IO4 r., 9 de mayo de 1768), operación que se repetiría en los mismos términos en octubre de 1768 , en mayo de 1769 y nuevamente en mayo de 1770 (AGN, JSRH-RRH, XIII-42-I-20, f. II2 r., I7 de octubre de I768; AGN, JSRH-RRH, XIII-42-I-2I, f. 45 V., 28 de mayo de 1769 y f. 66 r., 2 I de mayo de 1770). 
lucrativos de acreedores rioplatenses y los intereses defensivos de la Corona encontraban un punto de confluencia.

Desde luego, la estructuración del real situado como un campo de negocios para los acreedores de la Hacienda implicaba, concomitantemente, la existencia de aquella deuda flotante que la Hacienda sostenía con unas tropas a las que de manera sistemática retrasaba el pago de sus sueldos. En efecto, aquellos pagos de sueldos que ocupaban el primer lugar en los desembolsos de los fondos del situado, venían a saldar una morosidad sistémica en la cual la discrecionalidad también tenía lugar, a juzgar por las diferencias entre las moras con la plana mayor (2,7 meses en promedio), los regimientos veteranos (I2,3) y unas relegadas milicias $(28,4)$ (Wasserman, “Erogaciones”). Esta morosidad que la Real Hacienda sostenía con las tropas en Buenos Aires era la que imponía a los oficiales reales la necesidad de (o la conveniente legitimidad para) apelar a aquel crédito local: el omnipresente riesgo de deserción en las filas veteranas (Fradkin), así como el recuerdo de motines, saqueos y asaltos a casas de vecinos por la guarnición del presidio bonaerense como respuesta a demoras excesivas en el pago de sus sueldos — como ocurrió en I697 (Birocco)—, retroalimentaban el recurso de la Hacienda al crédito de quienes encontraban en el ramo de situados un potencial campo de negocios.

De este modo, la negociación protagonizada en el terreno fiscal por quienes detentaban crédito se apoyaba en última instancia sobre la compulsión, que tomaba forma en una sistemática morosidad en el pago de los sueldos, y cuyos límites estaban dados por la deserción o por el motín. Negociación y coerción se complementaban en la dinámica de un erario que operaba con base en el endeudamiento.

\section{Conclusión}

La reformulación institucional de la Real Hacienda borbónica en la región se materializaba en la evolución de las remisiones de recursos fiscales a Buenos Aires con fines defensivos, lo que da cuenta del reposicionamiento que le cabía al Río de la Plata en dicha reforma. El ramo del real situado vehiculizaba dicho proceso.

Sin embargo, ni la efectivización de la reforma institucional ni su materialización financiera prescindieron de la disputa política. La irregularidad y la insuficiencia de las remesas del real situado conducían a un déficit crónico que 
los oficiales de la Real Hacienda en Buenos Aires intentaban cubrir mediante la retención de recursos que debían liquidarse en otras plazas, o tomando fondos de fuentes fiscales en principio indisponibles. No obstante, el principal medio para sostener las acuciantes necesidades defensivas y militares en el estuario rioplatense y su frente marítimo consistió, primordialmente, en el crédito de los actores económicos locales.

En efecto, la llegada del situado era destinada en buena medida al reintegro de suplementos monetarios, abasto de víveres, provisión de materiales para el mantenimiento de establecimientos y expediciones, habilitación de embarcaciones y establecimientos, ganado en pie, medicina, pólvora, armamentos, hospedaje, vestimenta y útiles. Se trataba de anticipos otorgados por acreedores que identificaban en la demora del situado un riesgo aceptable para el acceso a moneda doble y a una virtual cuenta corriente con sede central en la Real Caja de Buenos Aires, que les permitía contar con herramientas para lubricar sus circuitos crediticios en el comercio, toda vez que la ocasional monetización de títulos de deuda contra la Real Hacienda y la disponibilidad de libranzas por cobrar en la Caja de Buenos Aires resultaban instrumentos de considerable importancia para acelerar y garantizar los intercambios crediticios en la economía comercial. Pero el financiamiento del dispositivo militar, dispuesto por una nueva estrategia defensiva imperial, no solo ofrecía a los comerciantes herramientas para agilizar su interacción económica: más de una década antes de constituirse en junta, los actores comerciales de Buenos Aires encontraban en dicho financiamiento una razón para respaldar la reestructuración institucional, a la cual condicionaban con su crédito ${ }^{33}$.

La totalidad material de la defensa imperial en el estuario rioplatense se sostenía, así, en el endeudamiento. Un sistema que ya no solo operaba en los intersticios del esquema local e interregional de la Hacienda, sino que participaba de los cauces jurídicamente instituidos para la gestión y distribución de los fondos del situado, incorporándose en sus registros contables. El real erario lograba así introducir en sus propios mecanismos institucionales a los flujos de crédito de los que dependía para garantizar la defensa; expresión financiera de una progresiva centralización en la estructura regional de la Hacienda borbónica.

33 Recién en $\mathbf{1 7 7 9}$, en el contexto de reformulaciones comerciales dispuestas por el Reglamento de Libre Comercio de octubre de 1778, los comerciantes de Buenos Aires darían forma orgánica a su colectivo constituyéndose jurídicamente como junta de comercio, prolegómeno de su conformación como consulado de comercio en 1794 (Ibarra; Kraselsky). 
Si la pervivencia de mecanismos que propiciaban la mediación de los actores locales en la gestión de recursos fiscales matizaba aquel modelo estrictamente coercitivo y centralizado de la organización imperial del siglo XVIII, que orientaba los propósitos centralizadores de las reformas institucionales en materia hacendaria, dichos mecanismos se incorporaban a la gestión administrativa de la Real Hacienda.

Hacer de Buenos Aires un polo de arrastre fiscal, replicando en los flujos hacendarios la dinámica de unos circuitos comerciales que venían consolidando al complejo portuario rioplatense como eje de un espacio económico era, por lo tanto, no solo un objetivo institucional de los oficiales reales de la Hacienda en Buenos Aires sino, igualmente, un coherente interés de sus acreedores ${ }^{34}$. Detrás de aquellos reclamos que desde 1768 los contadores, factores y tesoreros de Buenos Aires elevaban al virrey del Perú para volver financieramente efectiva la posición que le cabía al puerto en el esquema defensivo y hacendario, puede advertirse entonces una identidad de intereses con acreedores rioplatenses, que encontraban en la regularización y el incremento de los envíos del situado tanto la garantía de un retorno favorable para sus créditos a la Hacienda, como el sostenimiento de un campo de inversión asegurada. La jerarquización de Buenos Aires en el esquema regional de la Real Hacienda y su concreción mediante el aumento de fondos destinados a la defensa del estuario constituyeron, así, una órbita en la que los intereses militares y defensivos de la Corona confluían con los intereses lucrativos de los acreedores rioplatenses ${ }^{35}$.

Era otra deuda, sin embargo, coercitivamente impuesta, la que sostenía desde la base a este complejo equilibrio entre crédito y recursos fiscales: los sistémicos atrasos en el pago de los sueldos a las tropas veteranas y milicias. El endeudamiento de la Hacienda con los más bajos escalafones de los cuerpos de soldados y compañías milicianas constituía el terreno fértil sobre el cual se desplegaban los negocios articulados por acreedores y proveedores con la administración del situado. De esta manera, coerción y negociación se complementaban, en una relación que condicionaba y posibilitaba la centralización regional de la Hacienda con vértice en Buenos Aires.

34 Sobre el complejo portuario rioplatense y el espacio económico del Río de la Plata, véase Jumar.

35 En este sentido, Grafe e Irigoin han propuesto que la matriz redistributiva de la fiscalidad borbónica en América, expresada en el real situado, revelaba tanto un punto de confluencia entre los intereses de la Corona y los de sectores de las oligarquías locales, como una manifestación de su capacidad de negociación en el terreno fiscal. 


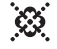 \\ B I B L I O G R A F í A}

\section{FUENTES PRIMARIAS}

\section{A. Archivos}

Archivo General de la Nación, Buenos Aires, Argentina (AGN).

Fondo Junta Superior de la Real Hacienda (JSRH).

Sección Ramos de la Real Hacienda (RRH).

XIII-42-OI-I9. "I768-I777. Caja de Buenos Aires. Resumen de Ajustes a las

Tropas, Embarcaciones de Su Majestad y Gastos. Razón de los Situados recibidos de Potosí".

XIII-42-I-20, XIII-42-I-2I, XIII-42-I-22, XIII-42-I-23, XIII-42-I-24, XIII-42-I-25.

"Libros Principales de Cargo y Data de Situados".

Fondo Escribania de Registro (ER).

Sección Escribanias Antiguas (EA).

IX-3956 “Tomo 34"; IX-3965 “Tomo 43"; IX-3966 “Tomo 44".

\section{FUENTES SECUNDARIAS}

Alemano, María Eugenia. "El imperio desde los márgenes: la frontera del Buenos Aires borbónico (1752-1806)”. Tesis de doctorado, Universidad de San Andrés, Buenos Aires, 2016.

Alves Carrara, Ángelo y Érnest Sánchez Santiró. Guerra y fiscalidad en la Iberoamérica colonial (siglos XVII-XIX). Juiz de Fora: Editorial UfJF-Instituto Mora, 2012.

Amadori, Arrigo. "Fiscalidad y consenso en el Virreinato del Perú, 1620-1650". América Latina en la Historia Económica, vol. 19, n. ${ }^{\circ}$ 2, 2012 , pp. 7-45. doi: 10.18232/alhe.vigi2.516.

Amaral, Samuel. "Las finanzas arcaicas: la atención del déficit fiscal en la Real Caja de Buenos Aires, 1789-1811". Investigaciones y Ensayos, n. 60 , 201 4, pp. 381-436.

---. "Seguridad monárquica, inseguridad republicana: la modernización de las finanzas públicas en Buenos Aires, 1790-1821”. Independencias iberoamericanas. Nuevos problemas y aproximaciones, dirigido por Pilar González Bernaldo de Quirós. Buenos Aires: Fondo de Cultura Económica, 2015, pp. 217-236. 
Bertrand, Michel. Grandeza y miseria del oficio. Los oficiales de la Real Hacienda de la Nueva España, siglos XVII y XVIII. México: Fondo de Cultura Económica, 20II. https://doi. org/ı0.4000/books.cemca.ıI28.

Bertrand, Michel, et al. "Haciendas locales y haciendas estatales en las monarquías francesa y española. La construcción territorial del poder (siglo xviII)”. Espacio, Tiempo y Forma, Serie IV, Historia Moderna, n. ${ }^{\circ}$ 27, 2014 , pp. 15-35. https://doi.org/10.5944/ etfiv.27.201 4.13700.

Beverina, Juan. El Virreinato de las provincias del Rio de la Plata. Su organización militar. Contribución a la "historia del Ejército argentino". 1935. Buenos Aires: Círculo Militar, 1992.

Biangardi, Nicolás. "Financiamiento y distribución del gasto en la Caja Real de Maldonado (Río de la Plata), 1782-1806”. América Latina en la Historia Económica, vol. 23, n. ${ }^{\circ}$, 2016, pp. 7-35. https://doi.org/10.18232/alhe.v23i2.707.

Birocco, Carlos María. “El presidio de Buenos Aires entre los Habsburgo y los Borbones: el ejército regular en la frontera sur del imperio español”. Hombres, poder y conflicto. Estudios sobre la frontera colonial sudamericana y su crisis, coordinado por Emir Reitano y Paulo Possamai. La Plata: Facultad de Humanidades y Ciencias de la EducaciónUniversidad Nacional de La Plata, 2015, pp. II7-I50.

Birolo, Pablo. Militarización y politica en el Rio de la Plata colonial. Cevallos y las campañas militares contra los portugueses, I756-1778. Buenos Aires: Prometeo, 2015.

Brewer, John. The Sinews of Power: War, Money, and the English State, I688-1783. Nueva York: Alfred A. Knopf, 1989.

Carbia, Rómulo y Enrique de Gandía. Historia de la ciudad de Buenos Aires, tomo I. Buenos Aires: Municipalidad de la Ciudad de Buenos Aires, 1939.

Clavero, Bartolomé. “Hispanus fiscus, persona ficta. Concepción del sujeto político en el ius commune moderno". Quaderni Fiorentini per la storia del pensiero giuridico moderno, n. ${ }^{\circ}$ II/I2, I982/1983, pp. 95-167.

Cuenca-Esteban, Javier. "Was Spain a Viable Fiscal-Military State on the Eve of the French Wars?”. The Spending of States. Military Expenditure during the Long Eighteenth Century: Patterns, Organization, and Consequences, I650-1815, editado por Stephen Conway y Rafael Torres Sánchez. Saarbücken: vdM, 201I, pp. 247-256.

Cuesta, Eduardo Martín. "Impuestos imperiales: la Caja Real de Buenos Aires (1700-1800)". Temas de historia argentina y americana, n. ${ }^{\circ} \mathrm{I} 4,2009$, pp. 27-56.

---. Precios, población, impuestos y producción. La economia de Buenos Aires en el siglo XVIII. Buenos Aires: Temas, 2009. 
Dedieu, Jean-Pierre. "De la merced a la deuda: la monarquía española y el crédito en el siglo XviII". Cambio institucional y fiscalidad. Mundo hispánico, I760-I850, editado por Michel Bertrand y Zacarías Moutoukias. Madrid: Casa de Velázquez, 2018, pp. 25-4I.

Del Río Chávez, Ignacio. "Implicaciones económicas y políticas del uso de libranzas de Real Hacienda en el norte de la Nueva España, I773-I8I0”. Moneda y mercado. Ensayos sobre los orígenes de los sistemas monetarios latinoamericanos, siglos XVIII a XX, editado por José Enrique Covarrubias y Antonio Ibarra. México: UNAM-Instituto Mora, 2013, pp. 67-84.

Dubet, Anne. "Reformar el gobierno de las Haciendas americanas antes de Gálvez: la actividad de la Contaduría General de Indias (1751-1776)". Anuario del Instituto de Historia Argentina, vol. 18, n. ${ }^{\circ}$ 2, 2018. https://doi.org/10.24215/2314257Xe073.

Fradkin, Raúl. "Guerras, ejércitos y milicias en la conformación de la sociedad bonaerense”. Fradkin, Historia, pp. 245-273.

---. Director. Historia de la Provincia de Buenos Aires. De la conquista a la crisis de I820. Buenos Aires: Unipe-Edhasa, 2012.

Frías, Susana. "La seguridad de la ciudad de Buenos Aires en la época de Martínez de Salazar”. Separata de Res Gesta, n. 34, 1995, pp. I19-1 45.

Galarza, Antonio. "Recaudar en los confines del imperio: impuestos y remesas en la Caja Real de Mendoza (Río de la Plata) a fines del período colonial I779-I810”. Revista de Indias, en prensa, 2017.

Gelman, Jorge. "El gran comerciante y el sentido de la circulación monetaria”. Revista de Historia Económica, vol. 5, n. 3, 1987, pp. 485-507. https://doi.org/10.1017/So212610900015329.

---. “La economía de Buenos Aires”. Fradkin, Historia, pp. 85-I2 I.

Gelman, Jorge y María Inés Moraes. “Las reformas borbónicas y las economías rioplatenses: cambio y continuidad". Iberoamérica y España antes de las independencias, 1700-I820. Crecimiento, reformas y crisis, compilado por Jorge Gelman, Carlos Marichal y Enrique Llopis. México: Instituto Mora / El Colegio de México, 2014, pp. 3 I-74.

González Enciso, Agustín. "El estado fiscal-militar, una reflexión alternativa”. Memoria y Civilización, n. ${ }^{\circ}$ II, 2008, pp. 27 1-295.

Grafe, Regina y Alejandra Irigoin. "Bargaining for Absolutism. A Spanish Path to Empire and Nation Building”. The Hispanic American Historical Review, vol. 88, n. ${ }^{\circ}$ 2, 2008 , pp. 173-209. https://doi.org/10.1215/00182168-2007-117.

Grieco, Viviana. La politica de dar en el Virreinato del Río de la Plata. Donantes, prestamistas, súbditos y ciudadanos. Buenos Aires: Prometeo, 2018.

Ibarra, Antonio. Mercado e institución: corporaciones comerciales, redes de negocios y crisis colonial. Guadalajara en el siglo XVIII. México: Universidad Nacional Autónoma de México, Bonilla Artiga Editores, 2017. 
Jumar, Fernando. Le commerce atlantique au Rio de la Plata, I680-1778, segunda edición (aumentada). La Plata: Facultad de Humanidades y Ciencias de la Educación - Universidad Nacional de La Plata, 20 Io.

Klein, Herbert y John TePaske. Las cartas cuentas de la Real Hacienda de la América española, siglos XVI a principios del siglo XIX. Edición electrónica. 1982, 1986, 1989. México: AMHE, 2005.

Kraselsky, Javier. "De las Juntas de Comercio al Consulado. Los comerciantes rioplatenses y sus estrategias corporativas, 1779-1794". Anuario de Estudios Americanos, vol. 64, n. ${ }^{\circ}$, 2007, pp. I45-169. https://doi.org/10.3989/aeamer.2007.v64.i2.84.

Levene, Ricardo. Investigaciones acerca de la historia económica del Virreinato del Plata, vol. I y II. 1927-1928. Buenos Aires: El Ateneo, 1952.

Levillier, Roberto. Correspondencia de la ciudad de Buenos Ayres con los Reyes de España. Documentos del Archivo de Indias, vols. I, II y III. Madrid: Biblioteca del Congreso Argentino, I9I8.

Marchena Fernández, Juan. "Llevar la guerra al otro lado del mundo: Reforma e Ilustración en las guerras de España contra Portugal. La gran expedición militar al Brasil y al Río de la Plata de 1776". El Estado en guerra. Expediciones navales españolas en el siglo XVIII, editado por María Baudot Monroy. Madrid: Polifemo, 2014, pp. 195-260.

Marichal, Carlos y Johanna von Grafenstein, coordinadores. El secreto del imperio español: los situados coloniales en el siglo XVIII. México: El Colegio de México / Instituto Mora, 2012.

Marichal, Carlos y Matilde Souto Mantecón. "La Nueva España y el financiamiento español en América: los situados para el Caribe en el siglo XviıI”. Marichal y Grafenstein, pp. 6I-94.

Mariluz Urquijo, José María. “El Tribunal Mayor y Audiencia Real de Cuentas de Buenos Aires”. Revista Española de Control Externo, vol. 2, n. ${ }^{\circ}$ 4, 2000 , pp. I29-158.

Martínez, Carolina. "Revelaciones de un manuscrito francés sobre las islas Malvinas: LouisAntoine de Bougainville en los contornos de la América hispana (1767)". Corpus. Archivos virtuales de la alteridad americana, vol. 7, n. ${ }^{\circ}$ 2, 2017. https://doi.org/10.4000/ corpusarchivos.1928.

Meisel, Adolfo. "El situado de Cartagena de Indias a fines del Siglo de las Luces”. Marichal y Grafenstein, pp. 193-212.

Mörner, Magnus. Actividades politicas y económicas de los jesuitas en el Río de la Plata. Buenos Aires: Hyspamérica, 1986.

Molina, Raúl. Las primeras experiencias comerciales del Plata. Buenos Aires: Talleres Gráficos Dorrego, 1966. 
Moutoukias, Zacarías. Contrabando y control colonial en el siglo XVII. Buenos Aires, el Atlántico y el espacio peruano. Buenos Aires: CEAL, 1988.

---. "Power, Corruption, and Commerce: The Making of the Local Administrative Structure in Seventeenth-Century Buenos Aires". The Hispanic American Historical Review, vol. 68, n. ${ }^{\circ}$, I988, pp. 77I-80I. https://doi.org/I0.2307/251568I.

---. "El crecimiento en una economía colonial de Antiguo Régimen: reformismo y sector externo en el Río de la Plata (1760-1796)”. Arquivos do Centro Cultural Calouste Gulbenkian, vol. 34, 1995, pp. 771-813.

North, Douglass, William Summerhill y Barry Weingast. "Order, Disorder and Economic Change: Latin America vs. North America”. Governing for Prosperity, editado por Bruce Bueno de Mesquita y Hilton Root. New Haven-Londres: Yale University Press, 2000 , pp. 17-58.

North, Douglass y Barry Weingast. "Constitutions and Commitment: The Evolution of Institutional Governing Public Choice in Seventeenth-Century England". The Journal of Economic History, vol. 49, n. ${ }^{\circ}$ 4, I989, pp. 803-832. https://doi.org/10.1017/ So022050700009451.

O’Brien, Patrick. “The Nature and Historical Evolution of an Exceptional Fiscal State and its Possible Significance for the Precocious Commercialization and Industrialization of the British Economy from Cromwell to Nelson”. Economic History Review, vol. 64, n. ${ }^{\circ}$ 2, 2011 , pp. 408-446. https://doi.org/IO.IIII/j.I 468-0289.2010.00538.x.

Pacheco Díaz, Argelia. "Las transferencias fiscales novohispanas a Puerto Rico: siglos XVIXIX”, Marichal y Grafenstein, pp. II5-I 42.

Pérez Herrero, Pedro. "Las libranzas empleadas en Nueva España durante la segunda mitad del siglo XviII". El crédito en Nueva España, coordinado por Guillermina Del Valle y María del Pilar Martínez López-Cano. México: Instituto Mora, 1998, pp. 83-105.

Pincus, Steve y James Robinson. "Faire la guerre et faire l'État: Nouvelles perspectives sur l'essor de l'État développementaliste”. Annales. Histoire, Sciences Sociales, vol. 7 I, n. ${ }^{\circ}$ I, 2016, pp. 5-36. https://doi.org/10.1353/ahs.2016.0036.

Pinto Bernal, José Joaquín. “Trasformaciones en el cargo de la caja real de Santafé, I739-I808. Un análisis cualitativo de su impacto administrativo. Anuario del Instituto de Historia Argentina, vol. 18, n. ${ }^{\circ}$ 2, 2018. https://doi.org/10.24215/2314257Xe074.

Rees Jones, Ricardo. El Superintendente Manuel Ignacio Fernández (I778-1783). Las reformas borbónicas en el Virreinato de Buenos Aires. Buenos Aires: Instituto de Investigaciones de Historia del Derecho, 1992.

Saguier, Eduardo. "La conducción de los caudales de oro y plata como mecanismo de corrupción. El caso del situado asignado a Buenos Aires por las Cajas Reales de Potosí en el siglo XVIII". Historia, n. ${ }^{24}$, 1989, pp. 287-317. 
Sánchez Santiró, Ernest. "El orden jurídico de la fiscalidad en la Real Hacienda de Nueva España: un análisis a partir de la calidad, el estado y la clase de los contribuyentes". Espacio, Tiempo y Forma, serie IV, n. ${ }^{\circ}$ 27, 2014, pp. 85-107. https://doi.org/10.5944/ etfiv.27.2014.13702.

---. Coordinador. El gasto público. Los Imperios ibéricos, siglo XVIII. Ciudad de México: Instituto Mora, 2015.

---. Introducción. Sánchez, El gasto público, pp. 7-22.

---. "Las reformas borbónicas como categoría de análisis en la historiografía institucional, económica y fiscal sobre Nueva España: orígenes, implantación y expansión”. Historia Caribe, vol. I1, n. ${ }^{\circ}$ 29, 2016, pp. I9-51. https://doi.org/10.15648/hc.29.2016.3.

---. "A la búsqueda de excedentes fiscales: las relaciones de valores, cargas y residuos de los reinos de Perú y Nueva España de la Contaduría del Consejo de Indias (1726)". Anuario del Instituto de Historia Argentina, vol. I8, n. ${ }^{\circ}$ 2, 2018. https://doi.org/10.24215/2314257Xe072.

Sandrín, María Emilia. "La actividad económica de los asentistas de víveres de la Marina de Montevideo, 1770-1810”. América Latina en la Historia Económica, vol. 21, n. ${ }^{\circ}$ I, 2014 , pp. 92-II4. https://doi.org/10.18232/alhe.v21iı.560.

Santilli, Daniel. “¿Perjudiciales o beneficiosas? La discusión sobre el impacto económico de las reformas borbónicas en Buenos Aires y su entorno”. Fronteras de la Historia, vol. I8, n. ${ }^{\circ}$ 2, 20I3, pp. 247-283. https://doi.org/10.22380/2027468844.

Solbes Ferri, Sergio. "Gasto militar y agentes privados. La provisión de uniformes para el ejército español en el siglo XVIII”. Tiempos Modernos, vol. I, n. 30, 2015.

Solbes Ferri, Sergio, Anne Dubet, Michel Bertrand y Rafael Torres Sánchez. "Actores políticos y actores privados en el gobierno de la Hacienda”. Tiempos Modernos, vol. I, n. 30,2015 .

Tandeter, Enrique. "El papel de la moneda macuquina en la circulación monetaria rioplatense”. Cuadernos de Numismática, tomo IV, n. I 4, I975, pp. I-I I.

---. "El eje Potosí-Buenos Aires en el imperio español”. Governare il mondo. L’imperio spagnolo dal XV al XIX secolo, dirigido por Massimo Ganci y Ruggero Romano. Palermo: Società Siciliana per la Storia Patria-Instituto di Storia Moderna-Gacoltà di Lettere, I991, pp. 185-202.

Torres Sánchez, Rafael. "Administración o asiento. La política estatal de suministros militares en la Monarquía española del siglo Xviı". Studia Historica: Historia Moderna, vol. 35, 2013, pp. 159-199. https://doi.org/10.14201/shhmo201335159199.

---. El precio de la guerra. El Estado fiscal-militar de Carlos III, I779-I783. Madrid: Marcial Pons, 2013. 
---. "El gasto público en la España del siglo XviıI”. Sánchez, El gasto, pp. 23-72.

Vaccani, María Evangelina. "El comandante de Resguardo de Montevideo. Francisco de Ortega y Monrroy: servicio real y defensa de honor en la sociedad de Antiguo Régimen”. Ponencia presentada en I Jornada de Jóvenes Investigadores en Historia, Instituto de Estudios Históricos-Universidad Nacional de Tres de Febrero, 2016.

Valle, Guillermina del. Donativos, préstamos y privilegios. Los mercaderes y mineros de la ciudad de México durante la guerra anglo-española de 1779-1783. Ciudad de México: Instituto Mora, 2016.

Wasserman, Martín. "Real situado y gestión patrimonial del recurso fiscal. Remesas para la defensa del puerto de Buenos Aires en el siglo xviı". Nuevo Mundo Mundos Nuevos, Débats, 2016. https://doi.org/10.4000/nuevomundo.69317.

---. "Los nombres propios del gasto. Procedencia, finalidades y receptores de los recursos erogados por la Real Caja de Buenos Aires en el siglo Xviı”. Escuela de Historia, vol. I5, n. ${ }^{\circ}$ 2, 2016, pp. I-22.

---. "Recursos fiscales para administrar el Imperio. La gestión de los ingresos al ramo de situados de Buenos Aires, 1766-1784". Estudios del ISHiR, vol. 7, n. ${ }^{\circ}$ 19, 2017, pp. 82-I15.

---. “La necesidad tan precisa'. Hacia la retención de recursos fiscales en la Real Caja de Buenos Aires”. Fiscalidad iberoamericana, siglos XVII-XX. Transiciones, diseños administrativos $y$ jurídicos. Coordinado por Luis Jáuregui y Carlos de Jesús Becerril Hernández. Ciudad de México: Instituto Mora, Universidad Anáhuac, 2018, pp. 29-64.

---. "Erogaciones fiscales, suministros militares y deudas. La distribución de los fondos del Real situado en Buenos Aires entre 1766 y 1772 ”. Anuario del Instituto de Historia Argentina, vol. 18, n. ${ }^{\circ}$ 2, 2018. https://doi.org/10.24215/2314257Xe075.

---. Las obligaciones fundamentales. Crédito y consolidación económica durante el surgimiento de Buenos Aires. Buenos Aires: Prometeo, 2018.

Wayar, Alejandro. "Las remesas fiscales intra-coloniales. Una aproximación desde las cajas del Tucumán. 1759-1808”. VJornadas uruguayas de Historia Económica. Montevideo: Asociación Uruguaya de Historia Económica, 20 Ir.

Yun Casalilla, Bartolomé. Introducción. "Entre el imperio colonial la monarquía compuesta. Élites y territorios en la Monarquía Hispánica (ss. XV I y XVII)”. Las redes del Imperio. Élites sociales en la articulación de la monarquia hispánica, I492-1714, dirigido por Bartolomé Yun Casalilla. Madrid: Marcial Pons, 2009, pp. II-38. 